Note

\title{
"A DERELICT IN THE STREAM OF THE LAW": OVERRULING BASEBALL'S ANTITRUST EXEMPTION
}

\author{
Morgen A. SUlLiVAN
}

\section{INTRODUCTION}

Baseball's antitrust exemption originated in 1922 when the Supreme Court held that professional baseball exhibitions did not constitute interstate commerce, thereby placing the sport outside the federal antitrust laws. ${ }^{2}$ Since the exemption's inception, scholars and courts have questioned its continuing validity and impact. Despite the Court's reaffirmation, fifty years later, of the exemption's solid entrenchment as an operation of stare decisis, ${ }^{3}$ lower courts continue to struggle to define the scope of the exemption. Some courts have limited the exemption to issues involving the reserve clause system. ${ }^{4}$ However, one court recently construed the exemption to apply to the entire business of baseball. ${ }^{5}$

1. Flood v. Kuhn, 407 U.S. 258, 286 (1972) (Douglas, J., dissenting). In Flood, Justice Douglas referred to the Supreme Court decision creating baseball's antitrust exemption as "a derelict in the stream of the law which we, its creators, should remove." Id.

2. See Federal Baseball Club, Inc. v. National League of Prof'l Baseball Clubs, 259 U.S. 200, 208-09 (1922).

3. See Flood, 407 U.S. at 282.

4. See, e.g., Piazza v. Major League Baseball, 831 F. Supp. 420, 421 (E.D. Pa. 1993); Butterworth v. National League of Prof'l Baseball Clubs, 644 So. 2d 1021, 1022 (Fla. 1994). Under the (now defunct) reserve clause system, an athlete's contract to play with a team for a term of years included a clause that reserved to the team the unilateral right of contract renewal. See John C. WeIsTART \& CYM H. LOWEll, The LAW OF SPORTS § 5.03 (1979); see also William S. Robbins, Comment, Baseball's Antitrust Exemption-A Corked Bat for Owners?, 55 LA. L. REV. 937, 958-60 (1995) (describing the rise of the reserve clause in baseball player contracts and its relation to the antitrust exemption).

5. See McCoy v. Major League Baseball, 911 F. Supp. 454, 457 (W.D. Wash. 1995); see also Robbins, supra note 4, at 939 n.12 (stating that baseball's exemption encompasses all antitrust concerns, "from franchise relocations, to competing leagues, to player restraints"). While 
Congress presumably eliminated the confusion surrounding the exemption's application to players' labor disputes when it passed the Curt Flood Act of 1998 . $^{6}$ Yet, while the Act intends to bring Major League Baseball players within the federal antitrust laws, it explicitly does not apply to other antitrust issues such as franchise relocation, Major League expansion, franchise ownership, marketing and licensing, and the minor league system. ${ }^{7}$ The limited and unsettled impact of the Curt Flood Act actually reinvigorates the debate over the scope of the original antitrust exemption. ${ }^{8}$ For example, the Minnesota Attorney General recently began conducting an antitrust inquiry into the Minnesota Twins franchise and Major League Baseball in connection with a dispute over the relocation of the team. ${ }^{9}$ However, the investigation has been postponed pending the Minnesota Supreme Court's decision as to whether baseball's antitrust exemption bars the state's civil investigative demands..$^{10}$ Another example demonstrating the exemption's unsettled scope involved a dispute between the New York Yankees and Major League Baseball. In 1997, the Yankees filed an antitrust suit against the League for interfering with a marketing deal between the franchise and the Adidas sporting goods company. ${ }^{11}$ Although the parties settled the suit, ${ }^{12}$ a fully adjudicated antitrust claim against the League by an owner could have forced a court to reexamine the exemption's applicability in nonlabor disputes. Since the Curt Flood Act does not clarify the exemption's scope and expressly refrains from addressing antitrust suits involving franchise relocation and marketing deals, ${ }^{13}$ cases like the ones involving the Twins and Yankees will continue to arise until the U.S. Supreme Court or Congress defines the scope of the exemption.

the Court in Flood reaffirmed baseball's antitrust exemption, it did not clarify the scope of the exemption. See infra notes 68-70 and accompanying text.

6. See Curt Flood Act of 1998, Pub. L. No. 105-297, § 2, 112 Stat. 2824, 2824 (to be codified at 15 U.S.C. $\$ 27$ a) ("It is the purpose of this legislation to state that major league baseball players are covered under the antitrust laws."); President Clinton Signs Curt Flood Act, AnTitrust Litig. ReP., Nov. 1998, at 17 (purporting that the Curt Flood Act "revokes baseball's 70-year-old antitrust exemption in labor matters").

7. See Curt Flood Act $\$ 3,112$ Stat. at 2824-25.

8. See infra Part III.C.

9. See John Gibeaut, Skybox Shakedown, 84 A.B.A. J., June 1998, at 68.

10. See Robert Whereatt, High Court Hears Arguments on State's Baseball Inquiry, STAR TRIB. (Minneapolis-St. Paul), Feb. 4, 1999, at 3B.

11. See Yanks and Baseball Settle Suit, N.Y. TIMES, May 1, 1998, at C4.

12. See id.

13. See Curt Flood Act of 1998, Pub. L. No. 105-297, § 3, 112 Stat. 2824, 2825 (to be codified at 15 U.S.C. $\$ 27 a)$. 
Considering the continuing debate regarding the exemption's foundation and scope, the Supreme Court, if given the chance, should explicitly overrule Flood in light of the statutory construction and stare decisis principles elucidated in State Oil Co. v. Khan, ${ }^{14}$ a recently decided antitrust case. In State Oil, the Court decided to review and overrule Albrecht v. Herald Co., ${ }^{15}$ an antitrust decision that time and experience had shown to be unworkable and unjustifiable. ${ }^{16}$ The analysis used by the State Oil Court to overrule precedent in Albrecht provides a basis for overruling baseball's antitrust exemption.

The Supreme Court's own doctrine of "positive inaction" constitutes the first barrier to revoking baseball's antitrust exemption. Positive inaction refers to the Court's aversion to overruling a decision that Congress has knowingly allowed to persist for many years. ${ }^{17}$ The doctrine is a straightjacket that makes a long-standing Supreme Court decision virtually reversal-proof because the Court, by invoking the positive inaction doctrine, insulates itself from reviewing and overruling its own decision, even if that decision was erroneous. However, the theory underlying positive inaction was questionable at its inception and subsequent decisions by the Court have further eroded its foundation. The State Oil Court's treatment of the positive inaction doctrine casts doubt on the validity of deferring to Congress's inaction when addressing the statutory construction and interpretation of antitrust laws.

After deconstructing the positive inaction doctrine, a review of the exemption's theoretical underpinnings should overcome stare decisis concerns and lead to the overruling of the exemption. The Court's recognition of obsolete factual conditions and scholarly criticism, as well as its dedication to principled legal reasoning, ought to overcome any reliance interests that would support the exemption's continued survival.

This Note will review the rise and decline of baseball's antitrust exemption and propose an analytical framework for its ultimate elimination. Part I provides background on the antitrust laws and their relationship to other professional sports. Part II describes the

\footnotetext{
14. 522 U.S. 3 (1997).

15. 390 U.S. 145 (1968).

16. See State Oil, 522 U.S. at 7.

17. See Flood v. Kuhn, 407 U.S. 258, 283-84 (1972) ("We continue to be loath ... to overturn those cases [establishing the exemption] judicially when Congress, by its positive inaction, has allowed those decisions to stand for so long and, far beyond mere inference and implication, has clearly evidenced a desire not to disapprove them legislatively.").
} 
development of baseball's antitrust exemption. Parts III and IV explain how the erosion of the positive inaction doctrine and the Supreme Court's willingness to reexamine outdated antitrust precedent lead to the conclusion that baseball's antitrust exemption should be overruled.

\section{ThE ANTITRUst LAws AND Other ProfessionAl SPORTS}

Pursuant to its Commerce Clause power, Congress enacted the Sherman $\mathrm{Act}^{18}$ in 1890 to prevent industrial monopolies from using their market power to disrupt and influence the national economy. ${ }^{19}$ Section 1 of the Act forbids contracts, combinations, and conspiracies that restrain trade. ${ }^{20}$ Section 2 prohibits monopolization as well as attempts and conspiracies to monopolize. ${ }^{21}$

While Congress intended that the antitrust laws would preserve free-market competition, the Act in fact outlaws only agreements or trade practices that unreasonably restrain trade and competition. ${ }^{22}$ Specifically, courts deem certain economic practices to be so anticompetitive that they are per se antitrust violations. ${ }^{23}$ However, courts adjudge many other practices under the "rule of reason" standard, which permits the defendant to justify the restrictions as reasonable restraints necessary to differentiate a product or to enable the particular industry to exist. ${ }^{24}$ Usually professional sports other than baseball are evaluated under the rule of reason. ${ }^{25}$

18. Sherman Act, ch. 647, 26 Stat. 209 (1890) (codified as amended at 15 U.S.C. $\S \S 1-7$ (1994)).

19. See Anthony Sica, Note, Baseball's Antitrust Exemption: Out of the Pennant Race Since 1972, 7 Fordham InTELl. Prop. Media \& ENT. L.J. 295, 314 (1996).

20. See 15 U.S.C. $\S 1$.

21. See id. \$2.

22. See Sica, supra note 19 , at 314.

23. See WeISTART \& LOWELL, supra note 4 , § 5.07. Courts often invoke the per se rule in summary proceedings to grant the plaintiff relief without an extensive factual inquiry. See id.

24. Under the rule of reason standard, a court inquires into the questioned practice's effects on competition, and then determines its legality or illegality based on whether the practice promotes or suppresses competition. See National Soc'y of Prof'l Eng'rs v. United States, 435 U.S. 679, 691 (1978).

25. See Weistart \& Lowell, supra note 4, § 5.07 (Supp. 1985); Stephen F. Ross, Reconsidering Flood v. Kuhn, 12 U. MiAMI ENT. \& SPORTS L. REV. 169, 178 (1994-1995) [hereinafter Ross, Reconsidering] (explaining the rule of reason and citing NCAA v. Board of Regents, 468 U.S. 85 (1984), as support for the proposition that "virtually all agreements among sports league owners will be governed by the rule of reason"). 
Once baseball became exempt from the antitrust laws, other professional sports argued that they also deserved exemption. However, the Supreme Court consistently rejected arguments advocating the expansion of baseball's exemption to include other sports. For example, in Radovich v. National Football League, ${ }^{26}$ the Court held that the precedent creating baseball's antitrust exemption did not shield professional football from the scope of the antitrust laws. ${ }^{27}$ The Radovich Court explicitly limited the exemption to the business of professional baseball. ${ }^{28}$ A few years later in Flood, the Court reiterated that no other interstate professional sport was exempt from the antitrust laws. ${ }^{29}$

Although professional sports other than baseball are generally subject to the antitrust laws, federal collective bargaining laws limit the antitrust liability of those sports. ${ }^{30}$ Specifically, under certain conditions, the law implicitly exempts franchise owners from antitrust claims involving player labor restraints arising out of collective bargaining agreements. ${ }^{31}$ Thus, all professional sports enjoy a limited antitrust exemption in the labor context. In addition, several professional sports, including baseball, enjoy a statutory antitrust

26. 352 U.S. 445 (1957).

27. See id. at 447-48. The decision involved a professional football practice analogous to the reserve clause contracting used in baseball. See id. at 449-50.

28. See id. at 451 ("[W]e now specifically limit the [exemption] to ... the business of organized professional baseball.").

29. See Flood v. Kuhn, 407 U.S. 258, 282-83 (1972) ("Other professional sports operating interstate-football, boxing, basketball, and, presumably, hockey and golf-are not so exempt.").

30. Sports, including baseball, did not clearly come under the coverage of the federal labor laws until 1969 when the National Labor Relations Board assumed jurisdiction over the sports industry. See Sica, supra note 19, at 326.

31. See Brown v. Pro Football, Inc., 518 U.S. 231, 235-36 (1996) (speculating that when Congress enacted the labor statutes in issue it intended to preclude judicial application of antitrust law to resolve labor disputes); Mackey v. National Football League, 543 F.2d 606, 612 (8th Cir. 1976) ("Since the basis of the nonstatutory exemption is the national policy favoring collective bargaining, .... under appropriate circumstances, we find that a non-labor group may avail itself of the labor exemption."); see also Sica, supra note 19, at 352 (describing several limitations on the availability of the nonstatutory exemption). More specifically, management loses the shield of the labor exemption only when a union votes to decertify itself. See Curt Flood Act Revokes Antitrust Exemption for Practices That Affect Employment of Major League Baseball Players, 20 No. 7 ENT. L. REP., Dec. 1998, at 4, 5 [hereinafter Curt Flood Act Revokes]. The Curt Flood Act does not affect the application of the nonstatutory labor exemption. See Curt Flood Act of 1998, Pub. L. No. 105-297, § 3, 112 Stat. 2824, 2825 (to be codified at 15 U.S.C. § 27a) ("Nothing in this section shall be construed to affect the application to organized professional baseball of the nonstatutory labor exemption from the antitrust laws."). 
exemption in the broadcasting arena. ${ }^{32}$ Where relevant, the following Parts of this Note consider the implications of subjecting other sports to antitrust laws while at the same time affording them labor and broadcasting exemptions.

\section{BASEBALL'S ANTITRUST EXEMPTION}

Baseball's antitrust exemption can be traced back to Federal Baseball Club, Inc. v. National League of Professional Baseball Clubs. ${ }^{33}$ In Federal Baseball, the plaintiff, a Federal League team, alleged that an illegal interleague conspiracy between the National and American Leagues had led to the dissolution of all the Federal League's franchises except for the plaintiff. ${ }^{34}$ The appellate court refused to acknowledge that an exhibition sport could constitute interstate commerce or trade warranting federal antitrust regulation. ${ }^{35}$ The Supreme Court affirmed the appellate court's holding, ruling that baseball games were "purely state affairs." ${ }^{\text {"T }}$ The Court reasoned that transporting players across state lines was incidental to an activity not considered trade or commerce in the first place. ${ }^{37}$ Since baseball did not involve interstate commerce, the Court held that the leagues

32. See 15 U.S.C. $§ 1291$ (1994) (exempting from antitrust laws "any joint agreement by persons engaging in or conducting the organized professional team sports of football, baseball, basketball, or hockey," by which any league of clubs participating in one of these sports sells or transfers the league's member clubs' rights to broadcast the games).

33. 259 U.S. 200 (1922).

34. See id. at 207. The plaintiff alleged that the National and American Leagues, through the use of reserve clauses in player contracts, prevented Federal League teams from securing sufficiently talented players. See National League of Prof'l Baseball Clubs v. Federal Baseball Club, Inc., 269 F. 681, 683 (D.C. Cir. 1920). While the reserve clause agreements constituted the underlying monopolistic devices providing a basis for the antitrust complaint, the alleged antitrust violation concerned the reserve clause's competitive impact on the leagues and franchises, not the impact on the players. See id. at 683-84, 687. The Supreme Court also cited practices apart from the reserve clause system as underlying motivations for the antitrust conspiracy claim. See Federal Baseball, 259 U.S. at 207 (stating that the complaint "alleges that the defendants destroyed the Federal League by buying up some of the constituent clubs and in one way or another inducing all those clubs except the plaintiff to leave their League"). Hence, doubt regarding the scope of the exemption reaches back to the Supreme Court's Federal Baseball decision.

35. See National League, 269 F. at 685 (declaring that a baseball game "is local in its beginning and in its end").

36. Federal Baseball, 259 U.S. at 208.

37. See id. at 209 ("[T] he exhibition, although made for money would not be called trade or commerce in the commonly accepted use of those words."). 
were not subject to the federal antitrust laws and that the plaintiff therefore had no basis for recovery under the Sherman Act. ${ }^{38}$

Thirty-one years later in Toolson v. New York Yankees, Inc., ${ }^{39}$ the Supreme Court was presented with the opportunity to reconsider its holding in Federal Baseball. ${ }^{40}$ Bound by precedent, the district court adhered to the Supreme Court's holding in Federal Baseball that baseball falls outside the definition of interstate commerce. ${ }^{41}$ The court of appeals affirmed that district court ruling in a single sentence opinion. ${ }^{42}$ In reconsidering baseball's antitrust exemption, the Supreme Court followed suit by devoting just a single paragraph to the case and affirming the dismissal of the plaintiff's claims based on "the authority of [Federal Baseball], so far as that decision determines that Congress had no intention of including the business of baseball within the scope of the federal antitrust laws." ${ }^{43}$

The Supreme Court's terse opinion left many questions unanswered and created some new ones. While the Federal Baseball Court had based its decision on a Commerce Clause interpretation, never addressing the substance of the antitrust claims underlying the case, the Toolson Court somehow uncovered an implied congressional intent regarding the antitrust laws in the Federal Baseball Court's discussion. The Toolson Court stated that Congress, and not the Supreme Court, should decide whether to overrule the Federal Baseball since "[t]he business [of baseball] has . . . been left for thirty years to develop, on the understanding that it was not subject to existing antitrust legislation." ${ }^{44}$ The Court's justification for deferring to Congress was that "Congress has had the [Federal Baseball] ruling under consideration but has not seen fit to bring such business [of baseball] un-

\footnotetext{
38. See id. at 208-09.

39. 346 U.S. 356 (1953).

40. See id. at 357 (acknowledging Federal Baseball as the controlling case pertaining to professional baseball's antitrust exemption).

41. See Toolson v. New York Yankees, Inc., 101 F. Supp. 93, 94-95 (S.D. Cal. 1951) ("If the Supreme Court was in error in its former opinion or changed conditions warrant a different approach, it should be the Court to correct the error.").

42. See Toolson v. New York Yankees, Inc., 200 F.2d 198, 199 (9th Cir. 1952) ("On the grounds and for the reasons stated in its opinion... the order of the District Court is affirmed.").

43. Toolson, 346 U.S. at 357.

44. Id. The Court was concerned with industry reliance on the exemption and the accompanying retroactive application of the law. See id. ("The present case asks us to overrule the prior decision and, with retrospective effect, hold the legislation applicable.").
} 
der these [antitrust] laws. ${ }^{, 45}$ However, the Toolson Court's rationale assumed that Congress always understood Federal Baseball to mean what the Toolson Court was then saying it meant-that Congress had no intention to include baseball under the antitrust laws-instead of what Federal Baseball actually said-that baseball is not trade or commerce. ${ }^{46}$ Regardless, the Court found that the plaintiff did not have a claim under federal antitrust laws. ${ }^{47}$

The Toolson dissent wanted to review Federal Baseball's factual underpinnings by reexamining baseball's status in relation to the Commerce Clause. ${ }^{48}$ Unlike the Toolson majority and the Federal Baseball Court, the Toolson dissent acknowledged the position that baseball "enjoys in the hearts of our people and the possible justification of special treatment for organized sports which are engaged in interstate trade or commerce." ${ }^{49}$ Still, the dissent argued that only Congress can affirmatively exempt interstate sports industries from the scope of the antitrust laws. ${ }^{50}$

By the time Flood v. Kuhn ${ }^{51}$ was decided nineteen years later, baseball was considered a "national pastime" worthy of special con-

\footnotetext{
45. Id.

46. In fact, as the Toolson dissent noted, subsequent to the decision in Federal Baseball, Congress investigated whether or not it had the power to regulate baseball under the Commerce Clause. See id. at 361 (Burton, J., dissenting). Such an inquiry must have resulted from a Commerce Clause-based understanding of Federal Baseball's holding. Interestingly, around the time of the congressional inquiry, four bills were introduced in Congress that would have created a complete antitrust exemption not only for baseball, but for all professional sports such that "[t]he law would no longer require competition in any facet of business activity of any sport enterprise." Id. at 361 n.9 (Burton, J., dissenting). However, the House Subcommittee on Study of Monopoly Power recommended the postponement of legislation until the courts clarified Federal Baseball. See Emmanuel Celler, Organized BAseball, H.R. ReP. No. 822002, at 134-36, 231-32 (1952).

47. See Toolson, 346 U.S. at 357 ("Without re-examination of the underlying issues, the judgments below are affirmed on the authority of Federal Baseball Club of Baltimore v. National League of Professional Baseball Clubs.").

48. See id. at 360 (Burton, J., dissenting) ("In the Federal Baseball Club case the Court did not state that even if the activities of organized baseball amounted to interstate trade or commerce those activities were exempt from the Sherman Act."). In United States v. International Boxing Club, Inc., 348 U.S. 236, the Justices disagreed about the Toolson Court's characterization of the Federal Baseball holding. The majority stated that "Toolson neither overruled Federal Baseball nor necessarily reaffirmed all that was said in Federal Baseball." Id. at 242. In his dissenting opinion, Justice Minton stated "[i]n Toolson ... we reaffirmed the holding of [Federal Baseball]." Id. at 251 (Minton, J., dissenting).

49. Toolson, 346 U.S. at 364 (Burton, J., dissenting).

50. See id. ("[T]he authorization of such [antitrust] treatment is a matter within the discretion of Congress.").

51. 407 U.S. 258 (1972).
} 
sideration by the courts. ${ }^{52}$ In Flood, the Supreme Court revisited the "troublesome and unusual situation" that arose when baseball's reserve clause system was challenged under federal antitrust laws. ${ }^{53}$ After reviewing the precedent and the history behind the antitrust exemption, the Court finally conceded that baseball was a business engaged in interstate commerce. ${ }^{54}$ However, the Court did not examine the case under the Commerce Clause. ${ }^{55}$ Instead, it held that while Federal Baseball and Toolson were possibly "unrealistic, inconsistent, or illogical" decisions, they were established "aberration[s]" restricted to baseball. ${ }^{56}$ The Court justified the aberrations based on "baseball's unique characteristics and needs," and concluded, without review of the underlying issues, that stare decisis entitled the exemption to judicial protection. ${ }^{57}$

The Court circumvented a full stare decisis discussion in Flood by invoking the "positive inaction" doctrine alluded to in Toolson. Applying the positive inaction doctrine, the Court concluded that Congress had no intention of subjecting baseball to the antitrust laws since it never passed remedial legislation in response to the prior holdings establishing the exemption. ${ }^{59}$ The Flood Court stated that

52. See id. at 267 (“The game is on higher ground; it behooves everyone to keep it there.”') (quoting Flood v. Kuhn, 309 F. Supp. 793,797 (S.D.N.Y. 1970)). This quote followed Justice Blackmun's lengthy description of the national history and pride associated with baseball. See id. at 260-64. In a footnote, Justice Blackmun also approvingly quoted a concurrence to the decision by the court of appeals, which argued that "[[b]aseball's welfare and future should not be for politically insulated interpreters of technical antitrust statutes but rather should be for the voters through their elected representatives."' Id. at $268 \mathrm{n} .9$ (quoting Flood v. Kuhn, 443 F.2d 264, 272 (2d Cir. 1971) (Moore, J., concurring)).

53. Id. at 269 .

54. See id. at 282.

55. The Flood Court reiterated the reliance and retroactive application concerns first alluded to in Toolson but did not examine the extent of the harm that would result if it did overturn the exemption. See id. at 283-84. Justice Marshall dissented, stating that the reliance and retroactivity problems could be minimized if antitrust laws were made applicable to baseball only prospectively. See id. at 293 (Marshall, J., dissenting).

56. Id. at 282 (quoting Radovich v. National Football League, 352 U.S. 445, 452 (1957)).

57. Id. The Court did not describe what constituted "baseball's unique characteristics and needs." Presumably, baseball's needs would have to consist of more than its status as a professional sport since the Court refused to exempt other professional sports from the federal antitrust laws. See id. at 282-83. The Court seemed to become mired in the cultural mystique of baseball - a revered and unique institution that should be beyond judicial tampering — to avoid addressing the actual concerns associated with opening an industry to retroactive antitrust attack. See id. at 260-64, 266-68 (discussing the esteem associated with the game and implying that courts should not interfere with the mechanics of the industry).

58. See supra notes 43-45 and accompanying text.

59. See Flood, 407 U.S. at 281, 283 (reasoning that although numerous legislative propos- 
Congress's inaction "has clearly evinced a desire not to disapprove [of prior decisions] legislatively." ${ }^{, 60}$ In other words, overruling the exemption would have undermined the "congressional intent" discovered in Toolson, ${ }^{61}$ as well as Congress's desire-as demonstrated by its affirmative legislative silence on the matter-to maintain the status quo. ${ }^{62}$ The Court held that Congress should be responsible for considering any reliance issues associated with a decision whether or not to overrule Federal Baseball. ${ }^{63}$

In Toolson the Court only referred in the vaguest terms to the reliance component considered in stare decisis review. For example, the opinion stated that "[t]he business [of baseball] has thus been left for thirty years to develop, on the understanding that it was not subject to existing antitrust legislation. The present case asks us to overrule the prior decision and, with retrospective effect, hold the legislation applicable." ${ }^{64}$ However, despite such allusions to reliance, the Toolson Court declined to evaluate the reliance argument, stating that Congress, not the Court, should determine what, if any, modifications should be made to baseball's judicially created antitrust exemption. ${ }^{65}$ Since the Court decided to abdicate to Congress the authority to review and overrule Supreme Court precedent, Toolson's holding primarily stands on the Court's positive inaction doctrine rather than any legitimate adherence to judicial precedent. ${ }^{66}$ Yet, in following Toolson and deferring to Congress, the Flood majority "failed to note ... that it was the Supreme Court and not Con-

als relating to baseball's antitrust exemption had been made since the Toolson decision, only bills that would have expanded the exemption to other sports gained much support).

60. Id. at 284 .

61. See supra note 43 and accompanying text.

62. See Flood, 407 U.S. at 283 ("Remedial legislation has been introduced repeatedly in Congress but none has ever been enacted.").

63. See id. at 283-84.

64. Toolson v. New York Yankees, Inc., 346 U.S. 356, 357 (1953); see also infra note 125 and accompanying text for a discussion regarding the factors considered in reexamining precedent.

65. See id. ("We think that if there are evils in this field which now warrant application to [the business of baseball] of the antitrust laws it should be by legislation. Without reexamination of the underlying issues, the judgments below are affirmed ....").

66. Although the Flood Court acknowledged reliance concerns, it did not examine them. Like the Toolson Court, the Flood majority deferred to Congress with respect to reliance issues. See Flood, 407 U.S. at 283-84 (stating that changes should be made "by the Congress and not by this Court"). 
gress that had created and perpetuated the illogical [antitrust] exemption." ${ }^{67}$

In addition to its legacy of illogic, the Flood Court left the antitrust exemption's scope unclear. At one point, the Court stated that baseball's "reserve system enjoy[ed] exemption from the federal antitrust laws. ${ }^{\prime 68}$ However, the Court concluded its decision by quoting a Toolson passage: "Congress had no intention of including the business of baseball within the scope of the federal antitrust laws." ${ }^{69}$ Hence, it is unclear whether the Court was holding that the exemption extends to all activities qualifying as "the business of baseball" or that the exemption is limited to the reserve clause..$^{70}$

Baseball's antitrust exemption consists of a unique blend of judicially mandated congressional deference, statutory construction, and an unusual application of stare decisis. For the Supreme Court to reexamine the exemption's underpinnings on the merits, a two-step analysis is required. First, the positive inaction doctrine itself needs to be reviewed in light of stare decisis considerations. Second, the Court should consider State Oil's teachings about unworkable, anachronistic, and factually unjustified antitrust precedent and recognize how the State Oil framework undercuts the positive inaction doctrine. After recognizing that the positive inaction doctrine lacks the strength to justify perpetuating the original Toolson holding, the Court should apply the State Oil analysis to reverse Flood and eliminate baseball's illogical antitrust exemption.

67. Larry C. Smith, Comment, Beyond Peanuts and Cracker Jack: The Implications of Lifting Baseball's Antitrust Exemption, 67 U. COLO. L. REV. 113, 122 (1996); see also Flood, 407 U.S. at 286 n.1 (Douglas, J., dissenting) ("While I joined the Court's opinion in [Toolson], I have lived to regret it; and I would now correct what I believe to be its fundamental error."); id. at 292 (Marshall, J., dissenting) ("It is this Court that has made [the baseball players] impotent, and this Court should correct its error."); $c f$. United States v. Reliable Transfer Co., 421 U.S. 397, 409 n.15 (1975) ("This Court, in other appropriate contexts, has not hesitated to overrule an earlier decision and settle a matter of continuing concern, even though relief might have been obtained by legislation.") (citing Burnet v. Coronado Oil \& Gas Co., 285 U.S. 393, 406 n.1

(1932) (Brandeis, J., dissenting)).

68. Flood, 407 U.S. at 282 (emphasis added).

69. Id. at 285 (emphasis added) (quoting Toolson, 346 U.S. at 357).

70. Subsequent to Flood, lower courts have debated the scope of the exemption. See supra notes 4-5 and accompanying text. 


\section{The Positive INACTION DOCTRINE}

The positive inaction doctrine has a lengthy history in Supreme Court jurisprudence. ${ }^{71}$ While the doctrine played a particularly important role in the Court's decision in Flood, ${ }^{72}$ it has subsequently been severely questioned with only infrequent resurgence delaying its ultimate abandonment.

\section{A. A Reexamination of the Positive Inaction Doctrine}

Ironically, prior to Toolson the Supreme Court had expressed strong sentiments against basing its decisions on congressional inaction. In Helvering $v$. Hallock, ${ }^{73}$ the court stated the following with regard to the importance of stare decisis in statutory interpretation:

It would require very persuasive circumstances enveloping Congressional silence to debar this Court from reexamining its own doctrines. To explain the cause of non-action by Congress when Congress itself sheds no light is to venture into speculative unrealities. ... This Court ... has from the beginning rejected a doctrine of disability at self-correction. ${ }^{74}$

The Hallock Court recognized that congressional failure to act on an erroneous decision should not influence the Court's ability to reexamine its own precedent. ${ }^{75}$ The Court justified its position by fo-

71. Professor Stephen Ross has contributed significantly to the discourse on the positive inaction doctrine as it pertains to baseball's antitrust exemption. See Ross, Reconsidering, supra note 25, at 182-88, 191-95, 201-04 (arguing that legislative inaction after Flood can be attributed to factors other than reliance concerns (e.g., lobbying)).

72. See William N. Eskridge, Jr., Overruling Statutory Precedents, 76 GEO. L.J. 1361, 1404 (1988) [hereinafter Eskridge, Overruling] ("Flood v. Kuhn is an unusually strong case for the acquiescence argument ....").

73. 309 U.S. 106 (1940).

74. Id. at 119-21 (footnotes omitted); see also Girouard v. United States, 328 U.S. 61, 69-70 (1946) (referring to Hallock for the proposition that neither congressional silence nor equivocal legislative history precludes the Court from reviewing its own doctrines). Hallock and Girouard were decided after Federal Baseball (Commerce Clause-based holding) but before Toolson (positive inaction-based holding). But cf. Apex Hosiery Co. v. Leader, 310 U.S. 469, 488 (1940) ("The long time failure of Congress to alter the [Sherman] Act after it had been judicially construed ... is persuasive evidence of legislative recognition that the judicial construction is the correct one.").

75. See Hallock, 309 U.S. at 120 ("Nor does want of specific Congressional repudiations ... serve as an implied instruction by Congress to us not to reconsider ... whether those decisions ... make for dissonance of doctrine."). But cf. Radovich v. National Football League, 352 U.S. 445, 449-52 (1957) (discussing the baseball antitrust exemption as illogical). In Radovich, the Court stated: "[T]he orderly way to eliminate error ... is by legislation and not by court decision. Congressional processes are more accommodative, affording the whole industry 
cusing on considerations beyond mere congressional unawareness that might explain congressional inaction: parliamentary tactics and strategy. ${ }^{76}$ In other words, the Court recognized that congressional silence might be a product of certain political procedural considerations rather than the substantive acceptance of a court decision. In addition, the Court alluded to the trouble that could result from deriving meaning from congressional inaction, since "we walk on quicksand when we try to find in the absence of corrective legislation a controlling legal principle." $" 77$

Given the Curt Flood Act, as well as the numerous bills introduced by Congress regarding baseball's antitrust status, it cannot be the case that Congress has been merely unaware of the Federal Baseball-Toolson-Flood trilogy. ${ }^{78}$ However, Congress had several strategic, parliamentary, and practical reasons, apart from doctrinal acceptance, justifying its failure to pass remedial antitrust legislation after Federal Baseball and its progeny. For example, prior to Toolson, baseball's interstate nature was still evolving. ${ }^{79}$ Although only one year prior to Toolson a congressional subcommittee had found that professional baseball did involve interstate commerce, ${ }^{80}$ exactly when baseball became a well-defined interstate activity remains unclear. As a matter of strategy, Congress may have decided not to regulate baseball until the industry had grown to the point where it clearly involved interstate commerce. Congressional inaction during the years

hearings and an opportunity to assist in the formulation of new legislation.... The whole scope of congressional action would be known in advance...." Id. at 452. It is possible the Radovich Court was making a special accommodation for the baseball industry in order to control for an erroneous decision that the Court made itself. Most likely, the Radovich Court's statement regarding the formulation of legislation was an attempt to address the reliance issues involved with overruling precedent, since Congress never specifically passed legislation exempting baseball from the antitrust laws in the first place. However, the Court has generally refused to defer to congressional silence when asked to examine reliance issues as they pertain to the antitrust laws. See infra notes 106-07 and accompanying text (discussing the Supreme Court's decision in State Oil v. Khan, in which the Court affirmed its longstanding ability to review its precedent as it pertains to antitrust laws).

76. See Hallock, 309 U.S. at 121 ("Various considerations of parliamentary tactics and strategy might [explain] the inaction ... of Congress.").

77. $I d$.

78. See Flood v. Kuhn, 407 U.S. 258, 281 (1972) (noting that "[l]egislative proposals have been numerous and persistent" and have dealt with both "the applicability or nonapplicability of the antitrust laws to baseball").

79. See Toolson v. New York Yankees, Inc., 346 U.S. 356, 358-60 (1953) (Burton, J., dissenting) (examining the growth of baseball following Federal Baseball).

80. See Emmanuel Celler, Organized Baseball, H.R. Rep. No. 82-2002, at 5 (1952) ("Inherently, professional baseball is intercity, intersectional, and interstate."). 
between Federal Baseball and Toolson may reflect lawmakers' tacit weighing of options in light of baseball's changing nature, rather than a silent endorsement of the antitrust exemption. ${ }^{81}$

The intricate political process underlying most legislative acts might also explain why Congress did not take any curative action. Professor William Eskridge has suggested several possible political explanations for Congress's inaction: general congressional apathy toward the Federal Baseball decision that in turn led to a lack of consensus on the remedy; disapproval of the decision by a congressional majority that might have been roadblocked by a minority; devotion of congressional attention to higher priorities; or strategic maneuvering by a congressional majority to exchange its support for curative legislation in return for other political promises. ${ }^{82}$

Members of Congress might also have endorsed or objected to proposed baseball legislation based on considerations distinct from their feelings on the validity of Federal Baseball and its progeny. For example, during the 1994 baseball players' strike "Congress was offering to repeal [the] antitrust exemption in return for a promise by the players to return to work." ${ }^{\prime 3}$ In addition, some Senate opposition to eliminating the exemption historically came from senators who feared that their states might lose their major league teams in competitive franchise relocations or that their minor league teams might suffer if restrictive player contracts became illegal. ${ }^{84}$ Also, after Tool-

81. Part of Congress's hesitancy to act also might have stemmed from the 1952 subcommittee report which concluded:

It would therefore seem premature to enact general legislation for baseball at this time. Legislation is not necessary until the reasonableness of the reserve rules has been tested by the courts.... [T] he courts may have to differentiate the unreasonable features of baseball's rules and regulations from those which are reasonable and necessary.

Id. at 231-32. Thus, the subcommittee's statement indicates that congressional silence might have been due to deference to the courts.

82. See Eskridge, Overruling, supra note 72, at 1405-06; see also William N. Eskridge, Jr., Interpreting Legislative Inaction, 87 MICH. L. REV. 67, 99-100 (1988) [hereinafter Eskridge, Interpreting] (approving of Hallock and further explaining the flaws in the Flood Court's interpretation of Congress's inaction).

83. Robbins, supra note 4, at 969 . The Curt Flood Act was motivated by the desire to give professional baseball players legal protection in order to curtail the numerous strikes and work stoppages that have plagued the industry. See President Clinton Signs Curt Flood Act, supra note 6 , at 17

84. See Daniel S. Mason \& Trevor Slack, Appropriate Opportunism or Bad Business Practice? Stakeholder Theory, Ethics, and the Franchise Relocation Issue, 7 MARQ. SPORTS L.J. 399, 407 (1997) (noting that "politicians are leery about losing a franchise while they are in office"); Smith, supra note 67, at 132 (discussing legislative opposition to reform efforts). 
son and Flood, developments in collective bargaining, along with other piecemeal legislation affecting baseball, might have redirected congressional efforts regarding the exemption by shifting Congress's focus to more discrete and less comprehensive remedial legislation. ${ }^{85}$ In short, congressional silence regarding the exemption can be characterized as a function of circumstance and the political process rather than an endorsement or disapproval of the Federal BaseballToolson-Flood trilogy.

In denouncing positive inaction, the Hallock Court was also wary of imputing to Congress a "hypothetical recognition of coherence" regarding a line of precedent. ${ }^{86}$ Ironically, the Flood Court boldly imputed to Congress an extreme and nonexistent "recognition of coherence" by inferring from congressional silence approval of the line of cases creating baseball's antitrust exemption, a line of cases that the Court itself viewed as an "aberration," and as "unrealistic, inconsistent, or illogical." "\$7 The Flood Court believed that Congress could sort out the precedent that evolved from Federal Baseball ${ }^{88}$ even though the Court itself was having trouble logically justifying baseball's exemption in light of the sport's interstate evolution and the different antitrust treatment for similar professional sports. ${ }^{89}$

Despite the language in Hallock and its clear implications for baseball, neither the Toolson nor the Flood majorities mentioned the Hallock opinion. Ignoring the political justifications for congressional inaction outlined in Hallock, the Flood Court confidently stated that it "continue[d] to be loath ... to overturn [Federal Baseball and Toolson] judicially when Congress, by its positive inaction, has al-

85. See Joseph A. Kohm, Jr., Baseball's Antitrust Exemption: It's Going, Going . . Gone!, 20 NOVA L. REV. 1231, 1248-49 (1996) (noting that statutory and nonstatutory labor law developments in the collective bargaining arena have placed the activities of players' labor unions beyond the scope of antitrust laws); Kathleen L. Turland, Note, Major League Baseball and Antitrust: Bottom of the Ninth, Bases Loaded, Two Outs, Full Count and Congress Takes a Swing, 45 SYRACUSE L. REV. 1329, 1350-51 (1995) (noting that the Sports Broadcasting Act of 1961 provides professional sports leagues with broadcasting rights exempt from the antitrust laws). The Curt Flood Act, the latest piecemeal legislation affecting baseball, does not foreclose the debate over the exemption since the Act is very ambiguous. See infra Part III.C.

86. Helvering v. Hallock, 309 U.S. 106, 122 (1940).

87. Flood v. Kuhn, 407 U.S. 258, 279 (1972) (quoting Radovich v. National Football League, 352 U.S. 445, 452 (1957)).

88. See id. at 284 (stressing that changes should be left to "Congress and not... this Court").

89. See Radovich, 352 U.S. at 452 (conceding certain similarities between baseball and football); Toolson v. New York Yankees, Inc., 346 U.S. 356, $357-59$ (1953) (Burton, J., dissenting) (discussing economic factors that suggest baseball is an interstate activity). 
lowed those decisions to stand for so long and, far beyond mere inference and implication, has clearly evinced a desire not to disapprove them legislatively." ${ }^{90}$ However, the Court had no reliable evidence that Congress refrained from passing legislation because it approved of the exemption. Instead, the majority just assumed that Congress approved of the exemption because it did not pass legislation. Professor Eskridge, reiterating the Supreme Court's reasoning in Hallock, points out that such an assumption is an extremely speculative basis for grounding legal reasoning since it does not account for the realities of the political process. ${ }^{91}$ In addition, Justice Douglas, a member of the Toolson majority, dissented in Flood and admonished the Flood majority for disregarding Hallock's wisdom regarding the dangers associated with reliance on congressional inaction. ${ }^{92}$

90. Flood, 407 U.S. at 283-84. "Congressional silence" should be considered synonymous with "positive inaction." The Hallock Court included parliamentary tactics and strategy as well as mere congressional unawareness as possible explanations of "congressional silence." See Hallock, 309 U.S. at 120-21. The Flood Court implicitly recognized the Hallock Court's concerns with congressional tactics and strategy when it stated: "Remedial legislation has been introduced repeatedly in Congress but none has ever been enacted. ... This, obviously, has been deemed [in Federal Baseball and Toolson] to be something other than mere congressional silence and passivity." Flood, 407 U.S. at 283 (emphasis added). In turn, the discussions in both Hallock and Flood lead to the conclusion that any tactical or strategic congressional action or inaction short of enacting a bill into law should be considered "congressional silence" or "positive inaction." Justice Scalia goes one step further and attributes no useful meaning to congressional activity occurring prior to enacting a bill into law:

The Constitution sets forth the only manner in which the Members of Congress have the power to impose their will upon the country: by a bill that passes both Houses and is either signed by the President or repassed by a supermajority after his veto.

Everything else the Members ... do is either prelude or internal organization.

United States v. Estate of Romani, 118 S. Ct. 1478, 1488-89 (1998) (Scalia, J., concurring) (citation omitted); see also Eskridge, Interpreting, supra note 82, at 96 ("In none of the more than fifty bills that Congress considered [regarding the application of the antitrust laws to baseball] did both Houses agree; hence, there was no article I legislative enactment entitled to authoritative consideration by the Court."). Justice Scalia probably would not bother to distinguish between "positive inaction" and "congressional silence" since, by his way of thinking, the activity underlying either carries no import as a judicial concern.

91. See Eskridge, Interpreting, supra note 82, at 98-100 (discussing the difficulties of drawing inferences from legislative inaction); Eskridge, Overruling, supra note 72, at 1405 ("The vagaries of the political process make it hard to determine what Congress's 'positive inaction' meant.").

92. See Flood, 407 U.S. at 287 n.3 (Douglas, J., dissenting) ("The Court's reliance upon congressional inaction disregards the wisdom of Helvering v. Hallock...."). The majority even acknowledged a case which supported Douglas's position. See id. at 283 (citing Boys Markets, Inc. v. Retail Clerks Union, Local 770, 398 U.S. 235, 241-42 (1970)). The Boys Markets Court stated that "in the absence of any persuasive circumstances evidencing a clear design that congressional inaction be taken as acceptance of [a judicial decision], the mere silence of Congress 
Many years after Flood, in Patterson v. McLean Credit Union, ${ }^{93}$ the Court revisited and reaffirmed its earlier position of avoiding reliance on congressional inaction as a factor in statutory stare decisis review. ${ }^{94}$ Although the Patterson Court acknowledged the heightened stare decisis considerations in cases involving statutory interpretation, ${ }^{95}$ it refused to conclude that "Congress' failure to overturn a statutory precedent is reason for [the] Court to adhere to it." ${ }^{96}$ The Court reasoned that it is impossible to state with confidence that this congressional failure to act represents affirmative approval of a decision. ${ }^{97}$ In addition, the Court warned against reading too much into the failures or partial successes of congressional bills as a means to ascertain congressional acceptance or rejection of Supreme Court rulings. ${ }^{98}$

After Patterson, the Court continued to chip away at the positive inaction doctrine. In Pension Benefit Guaranty Corp. v. LTV Corp., ${ }^{99}$ Justice Blackmun, author of the Flood opinion, chastised an appellate court for inferring congressional intent in a situation where Congress considered but failed to pass legislation..$^{100}$ Justice Blackmun reasoned as follows:

is not a sufficient reason for refusing to reconsider the decision." Boys Markets, 398 U.S. at 242.

93. 491 U.S. 164 (1989).

94. See id. at $175 \mathrm{n} .1$ (stating that it is wrong to infer "affirmative congressional approval" from legislative inaction). But see Monessen Southwestern Ry. Co. v. Morgan, 486 U.S. 330, 338 (1988) ("[W]e have recognized that Congress' failure to disturb a consistent judicial interpretation of a statute may provide some indication that 'Congress at least acquiesces in, and apparently affirms, that [interpretation]."”) (second alteration in original) (emphasis added) (quoting Cannon v. University of Chicago, 441 U.S. 677, 703 (1979)).

95. See Patterson, 491 U.S. at 175 n.1 ("[C]onsiderations of stare decisis have added force in statutory cases because Congress may alter what we have done by amending the statute."); infra notes 103-04 and accompanying text.

96. See Patterson, 491 U.S. at 175 n.1.

97. See id. ("It is 'impossible to assert with any degree of assurance that congressional failure to act represents' affirmative congressional approval of the Court's statutory interpretation.") (quoting Johnson v. Transportation Agency, 480 U.S. 616, 671-72 (1987) (Scalia, J., dissenting)).

98. See id. (discussing the danger of congressional "ratification"). In addition to the Supreme Court's case-by-case rejection of reliance on congressional inaction, at least one empirical study has concluded that the lack of an underlying pattern regarding congressional overrides of Supreme Court statutory interpretations "calls into question the view that congressional inaction necessarily implies approval" of the Court's interpretation. Michael E. Solimine \& James L. Walker, The Next Word: Congressional Response to Supreme Court Statutory Decisions, 65 TEMP. L. REV. 425, 451 (1992).

99. 496 U.S. 633 (1990).

100. See id. at 649-50 (criticizing the Second Circuit for inferring congressional approval of follow-on plans from Congress's failure to prohibit them in the 1987 amendments to the Em- 
[S]ubsequent legislative history is a "hazardous basis for inferring the intent of an earlier" Congress. It is a particularly dangerous ground on which to rest an interpretation of a prior statute when it concerns ... a proposal that does not become law. Congressional inaction lacks "persuasive significance" because "several equally tenable inferences" may be drawn from such inaction .... ${ }^{101}$

Although Pension Benefit was factually distinct from Flood, the Supreme Court has explicitly acknowledged that its holding in Pension Benefit regarding congressional inaction runs contrary to Flood's earlier pronouncement on the matter. ${ }^{102}$ In sum, since Flood, the Court has handed down a series of decisions that have seriously eroded the positive inaction doctrine's theoretical underpinnings.

\section{B. State Oil v. Khan, the Antitrust Laws, and Positive Inaction}

Normally the burden to justify overruling precedent is greater when statutory construction rather than constitutional interpretation is involved. ${ }^{103}$ The heightened burden for statutory review stems from

ployee Retirement Security Act of 1974). Later, in Ankenbrandt v. Richards, 504 U.S. 689 (1992), Justice Blackmun criticized the majority for concluding that congressional inaction constituted an "apparent acceptance of the Court's earlier construction of [a] diversity statute ...." Id. at 701 n.5. The majority cites Flood to counter Justice Blackmun's criticism. See id. (citing Flood v. Kuhn, 407 U.S. 258, 283-84 (1972)). Justice Blackmun unsuccessfully attempted to distinguish his position in Ankenbrandt from his discussion in Flood. See id. at 715-16 (Blackmun, J., concurring) ("It is one thing for this Court to defer to more than a century of practice unquestioned by Congress. It is quite another to defer on a pretext that Congress legislated what in fact it never did."). Ironically, he criticized the Court for going to "remarkable lengths to craft an exception that is simply not in the statute and is not supported by the case law.” Id. at 707 (Blackmun, J., concurring). Justice Blackmun's statement could just as easily undercut Toolson's invocation of Federal Baseball as support for the notion that "Congress had no intention of including the business of baseball within the scope of the federal antitrust laws." Toolson v. New York Yankees, Inc., 346 U.S. 356, 357 (1953).

101. Pension Benefit, 496 U.S. at 650 (citations omitted).

102. See Central Bank v. First Interstate Bank, 511 U.S. 164, 187 (1994) (citing Pension Benefit and Flood and admitting that the Court's decisions on congressional inaction "have not been consistent"); see also United States v. Estate of Romani, 118 S. Ct. 1478, 1488 (1998) (Scalia, J., concurring) ("First and most obviously, Congress can not express its will by a failure to legislate. The act of refusing to enact a law (if that can be called an act) has utterly no legal effect, and thus has utterly no place in a serious discussion of the law."); United States v. Wells, 519 U.S. 482, 495 (1997) ("[T]he significance of subsequent congressional action or inaction necessarily varies with the circumstances ....”); Brown v. Gardner, 513 U.S. 115, 121 (1994) (acknowledging that congressional silence lacks persuasive significance, especially when an administrative regulation is inconsistent with the controlling statute). But see Evans v. United States, 504 U.S. 255, 269-70 (1992) (using Congress's silence to buttress the prevailing statutory interpretation of the Hobbs Act).

103. See Patterson v. McLean Credit Union, 491 U.S. 164, 172 (1989) ("[T]he burden borne 
the idea that Congress can legislatively alter the Supreme Court's rulings on statutory interpretation but cannot as easily modify constitutional interpretation. ${ }^{104}$ However, the burden for antitrust review can be described as a hybrid between the constitutional and statutory burdens. ${ }^{105}$ In the recent case of State Oil Co. v. Khan, ${ }^{106}$ the Supreme Court reiterated the special status of antitrust review:

In the area of antitrust law, there is a competing interest [against the Court's reluctance to overrule decisions involving statutory interpretation], well represented in this Court's decisions, in recognizing and adapting to changed circumstances and the lessons of accumulated experience. Thus, the general presumption that legislative changes should be left to Congress has less force with respect to the Sherman Act in light of the accepted view that Congress "expected the courts to give shape to the statute's broad mandate by drawing on common-law tradition...." Accordingly, this Court has reconsidered its decisions construing the Sherman Act when the theoretical underpinnings of those decisions are called into serious question. ${ }^{107}$

In a statement reminiscent of Hallock's general pronouncement regarding the Court's ability to reconsider its precedent, the Court reserved the right to review its antitrust decisions. State Oil's instruction on reconsidering precedent is even more relevant than Hallock's since State Oil pertains specifically to the Court's authority to review antitrust law. The antitrust laws have been defined and shaped by the courts for over a century through the use of common law tradition because Congress purposely made the antitrust statutes textually broad. ${ }^{108}$ In turn, the courts that define and shape the antitrust law

by the party advocating the abandonment of an established precedent is greater where the Court is asked to overrule a point of statutory construction.").

104. See id. at 172-73 "Considerations of stare decisis have special force in the area of statutory interpretation, for here, unlike in the context of constitutional interpretation, the legislative power is implicated, and Congress remains free to alter what we have done."). But see Eskridge, Overruling, supra note 72, at 1363 (noting that the Supreme Court overruled or materially modified statutory precedents more than 80 times between 1961 and 1988 despite an alleged "super-strong presumption" against overruling statutory precedent).

105. Reviewing the precedent underlying baseball's antitrust exemption results in a hybrid analysis in itself since the original Commerce Clause-based exemption has evolved into an issue of statutory interpretation and application over time.

106. 522 U.S. 3 (1997).

107. Id. at 20-21 (emphasis added) (citations omitted).

108. See McNally v. United States, 483 U.S. 350, $372-73$ (1987) (Stevens, J. dissenting) ("Statutes like the Sherman Act... were written in broad general language on the understanding that the courts would have wide latitude in construing them to achieve the remedial purposes that Congress had identified.”); National Soc'y of Prof'l Eng'rs v. United States, 435 
ought to retain the capability to review and revise decisions when the theories underlying those decisions are called into doubt. ${ }^{109}$

Thus, two lines of thought lead to a rejection of the positive inaction doctrine as it applies to baseball's antitrust exemption. First, as it generally pertains to congressional intent, the positive inaction doctrine has been eroded by subsequent Supreme Court decisions. Second, the Supreme Court's State Oil decision has rebutted the presumption that only Congress should review and modify the application of antitrust statutes. Accordingly, the Court should reconsider and reject its former position on positive inaction as it pertains to baseball and should then review the exemption's theoretical underpinnings on their merits.

\section{The Curt Flood Act and the Positive Inaction Doctrine}

The Curt Flood Act, ${ }^{110}$ recently enacted by Congress, highlights the problem with relying on the positive inaction doctrine as a guiding legal principle. The Act, which affords Major League Baseball players a limited cause of action under the antitrust laws, ${ }^{111}$ has reinvigorated the debate over the scope and future of the antitrust exemption. When the Act was being considered, Representative Henry Hyde portrayed the Act as carving out a labor exception from a broader antitrust exemption. ${ }^{112}$ In contrast, Senator Patrick Leahy asserted that the Act "end[s] what is left of baseball's antitrust exemption." ${ }^{113}$ However, the Act explicitly states that its sole purpose is to

U.S. 679, 688 (1978) ("[Congress] expected the courts to give shape to the [Sherman Act's] broad mandate by drawing on common-law tradition."); see also Thomas C. Arthur, Farewell to the Sea of Doubt: Jettisoning the Constitutional Sherman Act, 74 CAL. L. REV. 266, 268-69 (1986) (discussing antitrust's "constitution-like vagueness"); Eskridge, Overruling, supra note 72, at 1381 ("Flood v. Kuhn is an almost comical adherence to the strict rule against overruling statutory precedents, particularly considering that the Sherman Act has developed essentially through a common law process.").

109. See Eskridge, Overruling, supra note 72, at 1377 (arguing that courts should "be given the leeway to experiment and overrule prior interpretations in a common law fashion").

110. Pub. L. No. 105-297, 112 Stat. 2824 (1998) (to be codified at 15 U.S.C. § 27a).

111. See id. § 2,112 Stat. at 2824.

112. See 144 CONG. REC. H9943 (daily ed. Oct. 7, 1998) (statement of Rep. Hyde) ("[The bill] leaves completely unchanged all aspects of the baseball exemption except for the narrow issue of the labor relations of major league players .... The bill was carefully drafted ... to leave the remainder of the exemption intact.").

113. 144 Cong. ReC. S10,417 (daily ed. Sept. 16, 1998) (statement of Sen. Leahy). However, it is not clear that Senator Leahy really meant that the Act would eliminate the exemption. See 144 Cong. REC. S9621 (daily ed. July 31, 1998) (statement of Sen. Leahy) ("The bill affects no pending or decided cases except to the extent that courts have exempted major 
afford major league baseball players the same protection under the antitrust laws that other professional athletes currently receive. ${ }^{114} \mathrm{~A}$ plain-meaning reading of the entire Act reveals that the statute should merely give major league baseball players the same antitrust protection already afforded to other professional players. ${ }^{115}$

If baseball's antitrust exemption only extends to players' labor disputes, the Act could be characterized as overruling Flood ${ }^{116}$ However, since several courts have held that the exemption extends to matters beyond labor disputes, ${ }^{117}$ the Act alternatively could be viewed as a congressional attempt to codify the broadest possible exemption by negative implication. ${ }^{118}$ Yet, because the Act does not expressly and affirmatively codify the baseball antitrust exemption and the courts have not clearly defined the exemption's scope, the Act cannot be said to overrule Flood or to alter the idea that the Supreme Court can resolve judicially the scope and validity of the exemption. ${ }^{119}$

league baseball clubs from the antitrust laws in their dealings with major league players.”).

114. See Curt Flood Act, § 2, 112 Stat. at 2824 ("[M]ajor league baseball players will have the same rights under the antitrust laws as do other professional athletes ...."); see also 144 CONG. REC. S9495 (daily ed. July 30, 1998) (statement of Sen. Hatch) ("[P]rofessional baseball players [will] have the same rights as other professional athletes ...."). The Act also states that it "does not change the application of the antitrust laws in any other context ...." Curt Flood Act $\S 2,112$ Stat. at 2824 .

115. See 144 CONG. REC. S9495 (daily ed. July 30, 1998) (statement of Sen. Hatch) ("With this historic agreement, I am confident that Congress will, once and for all, make clear that professional baseball players have the same rights as other professional athletes ...."); Statement by the President, 34 Weekly Comp. Pres. Doc. 2150, 2150 (Nov. 2, 1998) (signing the Curt Flood Act into law on Oct. 27, 1998) ("The [Curt Flood] Act in no way codifies or extends the baseball exemption and would not affect the applicability of those laws to certain matters that, it has been argued, the exemption would legitimately protect (including franchise relocation rules and the minor leagues).").

However, major league baseball players are still subject to the nonstatutory exemption. See supra notes 30-31 and accompanying text. Therefore, "in order for major league baseball players to take advantage of the Curt Flood Act, they would have to first vote to decertify their Players Association.... and that would be a truly 'scorched earth' and suicidal tactic." Curt Flood Act Revokes, supra note 31, at 5.

116. See Eldon L. Ham, Congress Takes a Swing at Baseball Monopoly, CHI. DAILY L. BuLL., Nov. 20, 1998, at 5 ("Congress has finally addressed the Major League Baseball antitrust exemption, eliminating the 76-year-old anomaly with little fanfare.").

117. See infra notes 169-72.

118. See Curt Flood Act $\S 2,112$ Stat. at 2824 ("[T]he passage of this Act does not change the application of the antitrust laws in any other context or with respect to any other person or entity."); supra note 112 and accompanying text.

119. Senator Hatch assured Senator Paul Wellstone of Minnesota that the Curt Flood Act would have no effect on the courts' resolution of the scope of the exemption beyond what the Act specifically covers. See 144 Cong. REC. S9621 (daily ed. July 31, 1998) (statement of Sen. Hatch) ("The bill does not change current law in any other context or with respect to any other 
In fact, the passage of the Curt Flood Act supports the idea that upholding Flood based on the positive inaction doctrine was ill founded. The Act demonstrates that congressional silence might be a product of something other than acquiescence in, or approval of, a Court decision. The Act originated from a collective bargaining agreement that required the owners and players to negotiate a limited repeal of the exemption. ${ }^{120}$ Although Congress could have used the Act as an opportunity to expressly codify or rebuke the Flood holding, it refrained from explicitly defining the exemption's scope. ${ }^{121}$ Congress's decision not to address baseball's antitrust exemption as a whole may constitute an endorsement of the broader exemption, or it might be the result of the practical political realization that Congress could not or did not want to convince a majority to pass such a law. Most likely, the Act was a short-term political compromise to facilitate a collective bargaining agreement between the owners and players. $^{122}$

Furthermore, the Curt Flood Act demonstrates that positive inaction is a poor indicator of congressional intent. Since the Act limits baseball's antitrust exemption, its passage invalidates the Flood Court's reliance on inferences drawn from the fact that "[the bills that passed one house or the other] would have expanded, not restricted, [baseball's] reserve system exemption to other professional

person.").

120. See 144 CONG. REC. H9943 (daily ed. Oct. 7, 1988) (statement of Rep. Hyde) ("This bill originates from a compromise struck during the last round of collective bargaining between the major league owners and the major league players."). The players had argued that the exemption contributed to prior labor disputes, while the owners argued that the exemption was irrelevant in the labor context since labor relations are covered by the nonstatutory exemption. See id.

121. See Curt Flood Act $\$ 3,112$ Stat. at 2824 ("No court shall rely on the enactment of this section as a basis for changing the application of the antitrust laws to any conduct, acts, practices, or agreements other than those set forth in subsection (a) [regarding actions affecting the employment of major league baseball players].").

122. See, e.g., S. REP. No. 105-118, at 4 (1997) ("Senators Hatch and Leahy subsequently made clear their willingness to substitute language designed to implement the intent of the owners' and players' agreement, believing that a bill which enjoyed both the owners' and players' support would be passed expeditiously."); 144 CONG. REC. H9943 (daily ed. Oct. 7, 1998) (statement of Rep. Hyde) ("This bill originates from a compromise struck during the last round of collective bargaining between the major league owners and . . p players. ... [B] oth the players and the owners were willing to support the repeal of the specific and narrow portion of the baseball exemption covering labor relations . ...”); 144 CONG. REC. S9497 (daily ed. July 31, 1998) (statement of Sen. Leahy) ("[While testifying, David Cone asked:] If baseball were coming to Congress ... [for] a statutory antitrust exemption, would such a bill be passed? The answer to that question is a resounding no."). 
league sports." ${ }^{123}$ Enactment of the Curt Flood Act shows that the Flood Court's speculation about Congress's desire to expand rather than to contract the exemption's scope was wrong. Time has proven inferences drawn from failed legislation to be poor proxies for reasoned judicial analysis. ${ }^{124}$ Three points become clearer after the passage of the Curt Flood Act: (1) the courts still have the authority to define the scope of the exemption; (2) the Supreme Court may define the scope of the exemption and overrule what remains of Flood; and (3) the positive inaction doctrine stands on extremely weak footing.

\section{STARE DECISIS CONSIDERATIONS}

Even if it overcomes the positive inaction doctrine, the Supreme Court still must decide whether or not stare decisis principles warrant upholding baseball's antitrust exemption. In general, the Supreme Court considers four issues when deciding whether or not to overrule a prior holding: (1) has the rule of law proven unworkable; (2) is reliance on the rule so great that overruling it would cause special hardship or inequity; (3) have related principles of law developed to the point that the old rule has become anachronistic or obsolete; and (4) have the facts underlying the rule changed so much that the old rule lacks significance or justification? ${ }^{125}$ While a departure from stare decisis requires special justification, "precedent[] [is] not sacrosanct .... [Courts] have overruled prior decisions where the necessity and propriety of doing so has been established." 126 As Justice Frankfurter pointed out:

[S]tare decisis embodies an important social policy. It represents an element of continuity in law, and is rooted in the psychologic need to satisfy reasonable expectations. But stare decisis is a principle of policy and not a mechanical formula of adherence to the latest decision ... when such adherence involves collision with a prior doctrine more embracing in its scope, intrinsically sounder, and verified by experience. $^{127}$

123. Flood v. Kuhn, 407 U.S. 258, 281 (1972).

124. See, e.g., Eskridge, Interpreting, supra note 82, at 94 ("Congress is a discontinuous decisionmaker.... Congress turns over every two years, and the 'intent' that is constitutionally most relevant is the intent of the Congress that actually enacted the legislation.").

125. See Planned Parenthood v. Casey, 505 U.S. 833, 854-55 (1992).

126. See Patterson v. McLean Credit Union, 491 U.S. 164, 172 (1989).

127. Helvering v. Hallock, 309 U.S. 106, 119 (1940). While abandoning Flood would not involve a return to a prior doctrine, it would encompass adopting a doctrine-the rule of rea- 
In State Oil, the Court's stare decisis analysis resulted in its decision to overrule antitrust precedent in light of changed factual circumstances, subsequent developments in the law, scholarly criticism, an aversion to lower courts' erroneous application of precedent, and reliance considerations. ${ }^{128}$ These same considerations should prompt Flood's overruling. In addition, the Court's overriding dedication to principled legal reasoning underscores the desirability of judicially overruling Flood.

\section{A. State Oil Co. v. Khan}

The Supreme Court took the opportunity in State Oil to overrule Albrecht v. Herald Co. ${ }^{129}$ a decision that had established that vertical maximum price fixing coupled with exclusive territorial restrictions constituted a per se antitrust violation under the Sherman Act. ${ }^{130}$ In overruling Albrecht, the Court held that the more flexible rule of reason standard should be applied when evaluating vertical maximum price fixing since subsequent judicial decisions and critical scholarship had shown that the Albrecht decision was based on false economic premises and that vertical maximum price fixing could have procompetitive effects. $^{131}$

In State Oil, the Court traced the convergence of two lines of cases in order to explain its decision to overrule Albrecht. In the first line of cases, the Court had deemed vertical minimum resale price fixing per se illegal and then subsequently extended per se illegality to vertical maximum resale price fixing. ${ }^{132}$ In the second line of cases, the Court had evaluated the antitrust implications of exclusive vertical territorial assignments. ${ }^{133}$ Initially, the Court did not rule that exclusive territorial assignments were per se illegal because too little was known about the competitive effects of such assignments. ${ }^{134}$ Four

\footnotetext{
son-that is more embracing in scope, intrinsically sounder, and verified by experience.

128. See State Oil Co. v. Khan, 522 U.S. 3, 20-22 (1997).

129. 390 U.S. 145 (1968)

130. See id. at 152-53.

131. See State Oil, 522 U.S. at 10-15. For a review of the difference between the per se rule and the rule of reason, see supra notes 23-24 and accompanying text.

132. See State Oil, 522 U.S. at 10-11 (citing Kiefer-Stewart Co. v. Joseph E. Seagrams \& Sons, Inc., 340 U.S. 211 (1951); United States v. Socony-Vacuum Oil Co., 310 U.S. 150 (1940); Dr. Miles Med. Co. v. John D. Park \& Sons, Co., 220 U.S. 373 (1911)).

133. See id. at 11-12 (citing United States v. Arnold, Schwinn \& Co., 388 U.S. 365 (1967); White Motor Co. v. United States, 372 U.S. 253 (1963)).

134. See White Motor Co., 372 U.S. at 253.
} 
years later, in United States v. Arnold, Schwinn \& Co., the Court reevaluated the territory assignment question and ruled such assignments per se antitrust violations. ${ }^{135}$ Albrecht brought the two lines of cases together because it involved the territorial assignments subject to maximum resale price fixing. ${ }^{136}$ In accord with the rationale underlying the two lines of cases, the Court held the restriction to be a per se antitrust violation. ${ }^{137}$

In addressing Albrecht's original underpinnings, the State Oil Court stated that the decision was based on "theoretical justifications for a per se rule" resulting from a "fear" that suppliers would be able to discriminate against dealers, restrict services to certain dealers, or use maximum price fixing to disguise minimum price fixing schemes. ${ }^{138}$ The State Oil Court reexamined Albrecht and found the decision to be based on false economic premises that gave rise to exaggerated concerns about potential antitrust injury. ${ }^{139}$ The Court also concluded that per se invalidation of procompetitive vertical maximum price fixing could actually harm the consumers and manufacturers that the antitrust laws were meant to protect. ${ }^{140}$ Considering also the scholarly criticism of the economic principles underlying $\mathrm{Al}$ brecht ${ }^{141}$ the Court's waning support of Albrecht in subsequent decisions, ${ }^{142}$ and the possible procompetitive effects of vertical restraints, ${ }^{143}$ the State Oil Court decided it was time to overrule its carte blanche invalidation of vertical maximum price fixing and adopt the

\footnotetext{
135. See Schwinn, 388 U.S. at 382.

136. See Albrecht v. Herald Co., 390 U.S. 145, 152-54 (1968).

137. See id.

138. See State Oil, 522 U.S. at 16-18.

139. See id. (stating that "there is insufficient economic justification for per se invalidation").

140. See id. at 18 (noting that "the per se rule ... could in fact exacerbate problems related to the unrestrained exercise of market power by monopolist-dealers").

141. See id. at 16-18 (citing, inter alia, Robert H. Bork, The Antitrust Paradox 28182 (1978); Roger D. Blair \& Gordon L. Lang, Albrecht After ARCO: Maximum Resale Price Fixing Moves Toward the Rule of Reason, 44 VAND. L. REV. 1007, 1034 (1991); John E. Lopatka, Stephen Breyer and Modern Antitrust: A Snug Fit, 40 ANTitrust Bull. 1, 60 (1995); Robert Pitofsky, In Defense of Discounters: The No-Frills Case for a Per Se Rule Against Vertical Price Fixing, 71 GEO. L.J. 1487, 1490 \& n.17 (1983)).

142. See id. at 14 (citing Atlantic Ritchfield Co. v. USA Petroleum Co., 495 U.S. 328, 335 \& n.5 (1990); 324 Liquor Corp. v. Duffy, 479 U.S. 335, 341-42 (1987); Arizona v. Maricopa County Medical Soc'y, 457 U.S. 332, 348 \& n.18 (1982)).

143. See id. at 14-15 (citing Phillip Areeda \& Herbert Hovenkamp, Antitrust Law II 340.30b (Supp. 1988); Roger D. Blair \& Jeffrey L. Harrison, Rethinking Antitrust Injury, 42 VAND. L. REV. 1539, 1553 (1989); Frank H. Easterbrook, Maximum Price Fixing, 48 U. CHI. L. REV. 886, 887-90 (1981)).
} 
rule of reason standard. ${ }^{144}$ When applied to baseball's antitrust situation, the same stare decisis considerations justify overruling the exemption and analyzing antitrust claims against professional baseball under the rule of reason.

\section{B. Stare Decisis and Baseball's Antitrust Exemption}

Just as the Supreme Court questioned in Albrecht whether or not certain acts should be per se invalid under the antitrust laws, the Court should be able to review baseball's antitrust exemption, which arguably makes all acts by team owners relating to the business of baseball per se valid under the antitrust laws. ${ }^{145}$ Albrecht was overruled in State Oil because it was grounded on theoretical economic "fears" rather than actual economic harm and because subsequent cases and literature called into question its theoretical underpinnings. ${ }^{146}$ Likewise, the Court ought to overrule baseball's antitrust exemption, an exemption that has been upheld because of exaggerated reliance fears, baseball's not-so-"unique characteristics and needs," and a discredited positive inaction doctrine. ${ }^{147}$ In addition, baseball's antitrust exemption should be overruled because the Federal Baseball-Toolson-Flood trilogy consists of cases based on obsolete factual premises and questionable legal reasoning.

1. The Intersection of State Oil and Flood. State Oil neither explicitly affirms nor rejects the rationale underlying baseball's antitrust exemption. However, the State Oil Court's brief discussion of Toolson and Flood reinforces the idea that the exemption is

144. See id. at 22 ("In overruling Albrecht, we of course do not hold that all vertical price fixing is per se lawful. Instead, vertical maximum price fixing ... should be evaluated under the rule of reason.").

145. When looking at a rule that makes a practice per se valid or per se invalid, consider what the Court said in Continental T.V., Inc. v. GTE Sylvania Inc.:

Per se rules thus require the Court to make broad generalizations about the social utility of particular commercial practices.... Once established, per se rules tend to provide guidance to the business community and to minimize the burdens on litigants and the judicial system ... . but those advantages are not sufficient in themselves to justify the creation of per se rules.

433 U.S. 36, 50 n.16 (1977) (citations omitted). In other words, per se rules that invalidate certain acts create reliance and administrative ease just as baseball's protective exemption creates reliance and administrative ease in the baseball industry. However, the ease that accompanies a blanket rule does not necessarily justify imposing that rule (especially if the generalizations regarding the commercial practices in issue have changed as they have in the baseball industry).

146. See supra notes 138-39 and accompanying text.

147. See supra Part III. 
unusual and that congressional inaction provides a weak reason to uphold precedent.

The State Oil Court refused to honor the Toolson-Flood positive inaction doctrine as grounds for upholding Albrecht's per se result. ${ }^{148}$ Although the Court's discussion of the baseball antitrust exemption is limited and somewhat vague, some inferences can be drawn based on what the Court did say. First, the Court refused factually to analogize Toolson and Flood to the antitrust issue in State Oil because the baseball exemption is "an aberration" based on "baseball's unique characteristics and needs." "149 Second, the Court rejected the idea that the Toolson-Flood positive inaction doctrine can be used as a general doctrine to uphold precedent. ${ }^{150}$ The Court hedged and said that even if the positive inaction doctrine was correct, it would be given little weight when legislative history neither clearly supports nor denounces a particular ruling. ${ }^{151}$

While Toolson and Flood can be distinguished from State Oil because the facts underlying those cases are exclusive to professional baseball, the Federal Baseball-Toolson-Flood cases can still be reevaluated on their merits under State Oil's theoretical rationale. ${ }^{152}$

148. See State Oil, 522 U.S. at 19. The Court stated the following regarding baseball's antitrust exemption:

Respondent's reliance on [Toolson and Flood] is similarly misplaced, because those decisions are clearly inapposite, having to do with the antitrust exemption for professional baseball, which this Court has described as "an aberration ... rest[ing] on a recognition and an acceptance of baseball's unique characteristics and needs." In the context of this case, we infer little meaning from the fact that Congress has not reacted legislatively to Albrecht. In any event, the history of various legislative proposals regarding price fixing seems neither clearly to support nor to denounce the per se rule of Albrecht.

Id. (citations omitted). In the quoted passage, the Court is addressing the respondent's assertion that congressional inaction supports the maintenance of Albrecht's per se rule precedent. See Respondent's Brief at 15, State Oil (No. 96-871). The respondent cites to Toolson and Flood for support. See id. at 17.

149. State Oil, 522 U.S. at 19 (quoting Flood v. Kuhn, 407 U.S. 258, 282 (1972)). Refusal to factually analogize does not mean that the same theoretical considerations cannot be analogized when certain factual issues become ripe for consideration. See infra note 152.

150. See State Oil, 522 U.S. at 19.

151. See id. (noting that "the history of various legislative proposals regarding price fixing seems neither clearly to support nor to denounce the per se rule of Albrecht"). This was the case with the legislative history regarding the bills introduced regarding baseball's antitrust exemption. See Flood v. Kuhn, 407 U.S. 258, 281 (1972) (stating that more than 50 congressional bills have been introduced regarding the applicability or inapplicability of antitrust laws to baseball since Toolson); see also Smith, supra note 67, at 132 (stating that more than a dozen congressional bills have been introduced to repeal baseball's antitrust exemption since World War II).

152. See State Oil, 522 U.S. at 15 (finding that the reasoning in Albrecht is "difficult to main- 
Like the history underlying Albrecht's reversal, judicial decisions and legislative activity subsequent to Toolson and Flood have significantly weakened the positive inaction doctrine and the antitrust exemption. ${ }^{15}$

Considering the mixed legislative history regarding baseball's antitrust exemption in light of State Oil leads to the conclusion that the positive inaction doctrine should be given little or no weight when the Court next revisits the exemption. In sum, State Oil's discussion of the Court's prerogative to review its own statutory interpretation of antitrust case law ${ }^{154}$ strongly undercuts an argument for upholding baseball's antitrust exemption based on the positive inaction doctrine. Furthermore, the State Oil Court's noncommittal reference to baseball's antitrust exemption sets the stage for an attack on, and overhaul of, the exemption's foundation. ${ }^{155}$

tain" in light of subsequent judicial decisions and legal scholarship).

153. See infra Part IV.B.2.

154. See supra notes 103-09 and accompanying text.

155. The State Oil Court's treatment of the Flood and Toolson precedent bears a resemblance to the Court's treatment of the Albrecht precedent in prior cases where, "although $A l$ brecht's continuing validity was not squarely before the Court, some disfavor with that decision was signaled." State Oil, 522 U.S. at 14. The State Oil Court gave weight to those signals in deciding to overrule Albrecht. See id. at 14-15. 
2. Changes in Factual Underpinnings and the Subsequent Development of Law. In overruling Albrecht, the State Oil Court relied in part on what it called decisions that "have hinted that the analytical underpinnings of Albrecht were substantially weakened." 156 The Supreme Court has acknowledged that the facts regarding professional baseball's involvement in interstate commerce have changed, undermining Federal Baseball's Commerce Clause-based holding. ${ }^{157}$ In addition, the Flood Court's rationale that baseball has "unique characteristics and needs" ${ }^{158}$ holds little weight given the development of other professional sports, such as basketball and football, which have survived and flourished without an antitrust exemption similar to baseball's exemption. Thus, both the factual and legal premises underlying the exemption have changed, necessitating close review of the exemption's continuing validity.

Subsequent developments of law have significantly limited the rationale for supporting baseball's antitrust exemption as well. The weakening of the positive inaction doctrine discussed in Part III demonstrates one way that a subsequent legal development has undermined the legal premise that justified maintaining the exemption. In addition, the adoption of the rule of reason as the antitrust standard in sports law demonstrates another way that a development in law has undermined the need for the exemption. ${ }^{159}$ Since the baseball industry's practices would be analyzed under the rule of reason absent the exemption, the industry would not automatically be subject to antitrust liability upon the exemption's extinction. ${ }^{160}$

3. Scholarly Criticism. In order to overcome stare decisis concerns and overrule Albrecht, the State Oil Court looked to

156. Id. at 14 .

157. See Flood v. Kuhn, 407 U.S. 258, 282 (1972) (holding that professional baseball is a business engaged in interstate commerce).

158. Id.

159. See NCAA v. Board of Regents of the Univ. of Okla., 468 U.S. 85, 100-04 (1984) (emphasizing that sports is "an industry in which horizontal restraints on competition are essential if the product is to be available at all" and adopting a rule of reason standard in its analysis).

160. Stripping baseball of its antitrust exemption would not automatically reveal antitrust violations since its practices would still be subject to a rule of reason legal analysis. See State Oil, 522 U.S. at 22 ("In overruling Albrecht, we of course do not hold that all vertical maximum price fixing is per se lawful. Instead, vertical maximum price fixing, like the majority of commercial arrangements subject to the antitrust laws, should be evaluated under the rule of reason."); Ross, Reconsidering, supra note 25, at 178 (citing NCAA as grounds for supposing that baseball would be subject to rule of reason analysis). 
another antitrust precedent that was overruled in part due to voluminous critical scholarly publications. ${ }^{161}$ Scholars have repeatedly attacked the underpinnings of baseball's antitrust exemption, for example through commentary on the weakness of the positive inaction doctrine ${ }^{162}$ and the negative legal and economic consequences that have resulted from the exemption. ${ }^{163}$ These criticisms, and the Supreme Court's acknowledgment of scholarly criticism's significance when deciding whether to review precedent,

161. See State Oil, 522 U.S. at 13. In Continental T.V., Inc. v. GTE Sylvania Inc., 433 U.S. 36 (1977), the Supreme Court overruled United States v. Arnold, Schwinn \& Co., 388 U.S. 365 (1967), citing, in part, significant criticisms in scholarly literature as its basis for reconsidering and overruling Schwinn.

162. See Eskridge, Interpreting, supra note 82, passim (commenting on weakness of positive inaction doctrine); Eskridge, Overruling, supra note 72, 1402-09 (same); Ross, Reconsidering, supra note 25, at 182-88, 191-95, 201-04 (suggesting that legislative inaction provides little justification for maintaining the exemption); Solimine \& Walker, supra note 98, at 451 (commenting on the meaninglessness of legislative inaction).

163. See H. Ward Classen, Three Strikes and You're Out: An Investigation of Professional Baseball's Antitrust Exemption, 21 AKRON L. REV. 369, 370-76, 387 (1988) (reviewing the economic structure of the professional sports industry and concluding that the exemption promotes economic inefficiency); Mark T. Gould, Perspective, Baseball's Antitrust Exemption: The Pitch Gets Closer and Closer, 5 SETON HALL J. SPORT L. 273, 279-80 (1995) (noting the adverse economic and competitive impacts which result from the exemption); Connie Mack \& Richard M. Blau, The Need for Fair Play: Repealing the Federal Baseball Antitrust Exemption, 45 FlA. L. REV. 201, 206-07 (1993) (describing owners' anticompetitive behavior under the exemption and its adverse effects on cities and fans); Ross, Reconsidering, supra note 25, at 169-70 (attributing some of baseball's woes to the monopolistic situation created by the exemption); Smith, supra note 67, at 135-37 (citing the economic loss caused by denying antitrust redress in the courts); Andrew Zimbalist, Baseball Economics and Antitrust Immunity, 4 Seton Hall J. SPORT L. 287 passim (1994) (weighing the economic pros and cons of lifting the exemption and concluding that baseball's exemption should be eliminated); Craig F. Arcella, Note, Major League Baseball's Disempowered Commissioner: Judicial Ramifications of the 1994 Restructuring, 97 COLuM. L. ReV. 2420, 2447, 2467 (1997) (noting that the exemption's elimination would be detrimental to franchise owners because owners have tendencies toward anticompetitive behavior and rely on the exemption to shield that behavior); Joshua Hamilton, Comment, Congress in Relief: The Economic Importance of Revoking Baseball's Antitrust Exemption, 38 SANTA ClaRA L. REv. 1223, 1248-49 (1998) (citing economic factors as grounds for revoking the exemption, but deferring to Congress to do so); Reynolds Holding, Do Baseball Bigwigs Deserve Special Treatment?, S.F. CHRON., Nov. 22, 1998, at 5 (noting that owners, fans, and minor league players might ultimately benefit economically without the antitrust exemption and acknowledging that the Curt Flood Act does not address or remedy these concerns). But see Gary Roberts, On the Scope and Effect of Baseball's Antitrust Exclusion, 4 SETON HALL J. SPORT L. 321, 323 (1994) (concluding that "trying to abolish the exclusion would be politically futile and unlikely to further the public interest"); Allan Selig, Major League Baseball and Its Antitrust Exemption, 4 SETON HALl J. SPORT L. 277, 281-82 (1994) (stating, as interim Chairman of the Executive Council of Major League Baseball, that the antitrust exemption should be maintained because the antitrust laws cause problems in professional sports). See generally WEISTART \& LOWELL, supra note 4, § 5.02, at 480-81 n.17; id. § 5.02, at 81 (Supp. 1985) (listing more articles on the subject). 
add further support to the proposition that baseball's antitrust exemption is ready for judicial reconsideration.

4. Confusing and Erroneous Decisions. Confusing and erroneous application of precedent by lower courts is another consideration in determining whether or not to overrule precedent. ${ }^{164}$ Lower courts have been prone to handing down confusing and possibly erroneous decisions as a consequence of the ambiguity surrounding baseball's antitrust exemption. ${ }^{165}$ Despite the fact that the Flood Court explicitly found that baseball constitutes interstate commerce, ${ }^{166}$ controversy in the courts regarding the exemption's scope remains. Recently, Major League Baseball has used the exemption to control the minor leagues, franchise relocations, and broadcasting rights. ${ }^{167}$ Analogous to lower courts' efforts to limit the precedent relied upon in Albrecht, ${ }^{168}$ some lower courts have limited the scope of baseball's antitrust exemption in situations where precedent would seem to dictate that a broader exemption be applied.

Lower courts disagree whether the exemption is limited to cases involving player labor disputes, whether it encompasses the entire business of baseball, or whether the exemption covers more than just labor disputes but less than the entire business of baseball. Several cases extend the exemption to the entire business of baseball without defining the scope of the business. ${ }^{169}$ Most recently, in McCoy v. Ma-

164. See Planned Parenthood v. Casey, 505 U.S. 833, 858 (1992) (specifying as a reason not to overturn precedent the fact that "courts building upon [the precedent will not] be likely to hand down erroneous decisions as a consequence").

165. For example, some courts limit the exemption to cases involving the reserve clause, some courts limit the exemption to the reserve clause and matters affecting the structure of baseball, and some courts apply the exemption to the entire business of baseball. See infra notes 169-77 and accompanying text. Anticompetitive harm could result if the exemption is unclear or defined to be overly broad because some practices will be deemed legal when they should be invalidated under the antitrust laws.

166. See Flood v. Kuhn, 407 U.S. 258, 282 (1972) ("Professional baseball is a business ... engaged in interstate commerce.").

167. See Smith, supra note 67, at 124 n.81.

168. See State Oil Co. v. Khan, 522 U.S. 3, 13 (1997) (discussing the overruling of Schwinn); Continental T.V., Inc. v. GTE Sylvania Inc., 433 U.S. 36, 48 n.14 (1977) (supporting the proposition that lower courts have sought to limit Schwinn's reach) (citing Janel Sales Corp. v. Lauvin Parfums, Inc., 396 F.2d 398, 406 (2d Cir. 1986); Adolph Coors Co. v. FTC, 497 F.2d 1178, 1187 (10th Cir. 1974); Colorado Pump \& Supply Co. v. Febco, Inc., 472 F.2d 637 (10th Cir. 1973); Tripoli Co. v. Wella Corp., 425 F.2d 932, 936-38 (3d Cir. 1970); Carter-Wallace, Inc. v. United States, 449 F.2d 1374, 1379-80 (Ct. Cl. 1971)).

169. See, e.g., Professional Baseball Sch. \& Clubs, Inc. v. Kuhn, 693 F.2d 1085, 1085-86 
jor League Baseball, ${ }^{170}$ a district court held that the exemption applied to the "business of baseball" and not just to the reserve clause. ${ }^{171}$ However, other courts have stated that the exemption, while broad, does not include carte blanche antitrust immunity. ${ }^{172}$ Interestingly, Toolson was decided with two companion baseball antitrust cases that did not involve the reserve clause, yet the Toolson holding applied to all three cases, suggesting that the Court understood the exemption to extend beyond the reserve clause. ${ }^{173}$

Other courts have reasoned that the exemption extends only to the reserve clause. In Piazza v. Major League Baseball, ${ }^{174}$ the district court engaged in a lengthy discussion of the exemption's scope and

(11th Cir. 1982) ("Although it may be anomalous, the exclusion of the business of baseball from the antitrust laws is well established."); Charles O. Finley \& Co. v. Kuhn, 569 F.2d 527, 541 (7th Cir. 1978) (reasoning, in a case involving a player assignment dispute between an owner and the commissioner, that "[d] espite the two references in the Flood case to the reserve system, it appears clear from the entire opinions in the three baseball cases ... that the Supreme Court intended to exempt the business of baseball, not any particular facet of that business, from the federal antitrust laws") (footnotes omitted); Salerno v. American League of Prof'l Baseball Clubs, 429 F.2d 1003, 1005 (2d Cir. 1970) (affirming the dismissal of a claim involving a labor dispute between umpires and the American League because Federal Baseball and Toolson held that "professional baseball is not subject to the antitrust laws"); Portland Baseball Club, Inc. v. Kuhn, 368 F. Supp. 1004, 1007 (D. Or. 1971), aff'd, 491 F.2d 1101 (9th Cir. 1974) (dismissing an antitrust claim based on a franchise expansion dispute "[o]n the basis of numerous cases which exempt professional baseball from the application of the federal antitrust laws").

170. 911 F. Supp. 454 (W.D. Wash. 1995).

171. Id. at 457. In McCoy, a case involving a player labor dispute, the court reiterated that "the great weight of authority recognizes that the scope of the antitrust exemption covers the entire business of baseball." Id.

172. See, e.g., Charles O. Finley, 569 F.2d at 541 n.51 ("We recognize that this exemption does not apply wholesale to all cases which may have some attenuated relation to the business of baseball.”); Postema v. National League of Prof'l Baseball Clubs, 799 F. Supp. 1475, 1489 (S.D.N.Y. 1992) (holding that an umpire labor dispute was not barred by the exemption because "although the baseball exemption does immunize baseball from antitrust challenges to its league structure and its reserve system, the exemption does not provide baseball with blanket immunity for anti-competitive behavior in every context in which it operates" and "[a]nticompetitive conduct toward umpires is not an essential part of baseball"); Henderson Broad. Corp. v. Houston Sports Ass'n, 541 F. Supp. 263, 265, 271 (S.D. Tex. 1982) (refusing to extend baseball's exemption to a broadcasting dispute because the exemption only covers integral aspects of baseball, such as leagues, clubs, and players, and not related activities that serve to enhance the sport's commercial success); State v. Milwaukee Braves, Inc., 144 N.W.2d 1, 15 (Wis. 1966) ("We venture to guess that this exemption does not cover every type of business activity ... but it does seem clear that the exemption at least covers the agreements and rules which provide for the structure of the organization and the decisions which are necessary steps in maintaining it.").

173. See Smith, supra note 67, at 119 n.43.

174. 831 F. Supp. 420 (E.D. Pa. 1993). 
concluded that the Flood Court had limited the exemption to the reserve clause. ${ }^{175}$ Citing principles of stare decisis, the court in Piazza followed a restrictive reading of Flood. ${ }^{176}$ In contrast, also citing principles of stare decisis, another district court stated that Piazza incorrectly interpreted Flood. ${ }^{177}$ Thus, case law subsequent to the Federal Baseball-Toolson-Flood trilogy demonstrates that the exemption's scope remains unclear. Conflicting and erroneous decisions are still being promulgated after Flood.

175. See id. at 436-38.

176. See id. (finding that a dispute over franchise relocation was not barred by the exemption because the Flood Court's specific references to the reserve clause and the principle of "result stare decisis" served to limit the exemption to reserve clause disputes); see also Butterworth v. National League of Prof'l Baseball Clubs, 644 So. 2d 1021, 1025 (Fla. 1994) (following the Piazza rationale despite the fact that "Piazza is against the great weight of federal cases regarding the scope of the exemption").

177. See McCoy v. Major League Baseball, 911 F. Supp. 454, 457 (W.D. Wash 1995). 
5. Reliance Considerations. In deciding whether or not to overrule precedent, the Supreme Court considers the harm that would be caused to parties who have reasonably relied on the case law in question. ${ }^{178}$ Apart from the positive inaction doctrine, the Flood and Toolson Courts appeared to be most concerned with the abstract reliance issues associated with the exemption. ${ }^{179}$ Although the Flood and Toolson Courts framed their reliance concerns in the context of retroactive litigation, ${ }^{180}$ those Courts never specifically identified the extent, if any, of the potential damage that would be caused by eliminating the exemption. ${ }^{181}$

While Flood vaguely referenced possible reliance interests, State Oil more narrowly defined reliance in the modern antitrust setting. The State Oil Court looked closely at the economic effects incurred by lifting the per se rule. ${ }^{182}$ More specifically, the State Oil Court overruled Albrecht, perhaps in spite of any reliance concerns, after determining that the fear of possible antitrust injury was overexaggerated $^{183}$ and that the per se rule could actually harm manufacturers and consumers. ${ }^{184}$

178. See Planned Parenthood v. Casey, 505 U.S. 833, 855 (1992) (citing as a consideration in determining whether to overrule precedent, "whether the rule's limitation on state power could be removed without serious inequity to those who have relied upon it").

179. See Flood v. Kuhn, 407 U.S. 258, 283 (1972) (expressing "concern about the confusion and the retroactivity problems that inevitably would result with a judicial overturning of $\mathrm{Fed}$ eral Baseball"); Toolson v. New York Yankees, Inc., 346 U.S. 356, 357 (1953) (declining to hold antitrust laws applicable, and "with retrospective effect," partially because baseball had "been left for thirty years to develop, on the understanding that it was not subject to existing anti-trust legislation").

180. See Flood, 407 U.S. at 283 ("The Court has expressed concern about the confusion and the retroactivity problems that inevitably would result with a judicial overturning of Federal Baseball."); Toolson, 346 U.S. at 357 ("The business has thus been left for thirty years to develop, on the understanding that it was not subject to existing antitrust legislation. The present cases ask us to overrule the prior decision and, with retrospective effect, hold the legislation applicable.").

181. The Court never really identified the reliance interests, see Flood 407 U.S. at 283; Toolson, 346 U.S. at 357, because it never made it past the positive inaction doctrine to reconsider the exemption on its merits. See Flood, 407 U.S. at 283-84 ("We continue to be loath ... to overturn [Federal Baseball and Toolson] when Congress, by its positive inaction, has allowed those decisions to stand for so long, and ... has clearly evinced a desire not to disapprove them legislatively.").

182. See State Oil Co. v. Khan, 522 U.S. 3, 18 (1997).

183. See id. ("Not only are the potential injuries cited in Albrecht less serious than the Court imagined, the per se rule established therein could in fact exacerbate problems related to the unrestrained exercise of market power by monopolist-dealers."). More specifically, the restraint at issue might possibly have procompetitive effects. See id. at 14-15 (citing Atlantic Richfield Co. v. USA Petroleum Co., 495 U.S. 328, 343 n.13 (1990)). In addition, the State Oil Court indicated a greater willingness to overrule antitrust precedent based "solely upon hypo- 
Likewise, the Toolson and Flood Courts' fear of the potential injury that would be caused by lifting the exemption is also overexaggerated. ${ }^{185}$ At the time Flood was decided, the Court accepted the argument that abolishing the reserve clause would be detrimental to baseball because congressional findings and even the plaintiff's witnesses conceded that the reserve clause was not "wholly undesirable."" 186 As with Albrecht, scholarship and practice have shown otherwise. The end of the reserve system did not reduce competition for players, but rather seems to have enhanced competition for professional baseball players. ${ }^{187}$ This enhancement factor runs contrary to the rationale underlying the reserve clause. Taking the reliance argument to its extreme, some would argue that collective bargaining law has made the antitrust exemption meaningless as far as players' labor issues are concerned. ${ }^{188}$ In addition, if baseball lost its antitrust

thetical effects" of price fixing. Id. at 19.

184. See id. at 18 ("[B]oth courts and antitrust scholars have noted that Albrecht's rule may actually harm consumers and manufacturers.").

185. See Flood, 407 U.S. at 286 (Douglas, J., dissenting) ("Only a romantic view of a rather dismal business account over the last 50 years would keep that derelict [of law that is Federal Baseball] in midstream." (footnote omitted)); Ross, Reconsidering, supra note 25, at 176 (observing that since the reserve clause was effectively abolished in 1976, owners' claims of potential injury have been disproved by greater competitive balance).

186. Flood, 407 U.S. at 267 (quoting Flood v. Kuhn, 316 F. Supp. 271, 275 (S.D.N.Y. 1970)); see also id. at 267, 272, 282 (deferring to trial court and congressional assessments that "some form of reserve on players is a necessary element of the ... sport"' (quoting Flood, 316 F. Supp. at 275 (emphasis added))).

187. See Ross, Reconsidering, supra note 25, at 176 ("[A]fter almost two decades of experience with free agency, the evidence demonstrates overwhelmingly that ending the reserve system destroyed neither baseball nor its integrity. In fact ... academic studies have shown that the reserve system actually hurt competitive balance in baseball."). The fact that developments in labor law weaken the need for the antitrust exemption also supports the idea that subsequent legal developments have weakened the theoretical underpinnings justifying the exemption. See supra note 85 and accompanying text.

188. See Kohm, supra note 85, at 1248 ("[A]ny repeal of baseball's exemption would have minimal impact in terms of what legal recourse would be available to the players against the owners due to both the statutory and nonstatutory labor law exemptions from antitrust law."); Robbins, supra note 4, at 938 (stating that the collective bargaining antitrust exemption would cover all labor issues raised under baseball's exemption). While the reserve clause is now defunct, issues such as salary caps have kept alive the debate over the antitrust exemption. See Ross, Reconsidering, supra note 25, at 197. But cf. Robbins, supra note 4, at 962 (stating that application of antitrust remedies will not solve baseball players' labor problems). Yet, even Robbins acknowledges that the current wrangling between players and owners over the exemption seems troublesome if the exemption is truly meaningless. See id. at 970 . While Robbins dismisses the current debate over the exemption as a distraction or a public relations device, see id. at 970-71; cf. Holding, supra note 163, at 5, the McCoy decision and the baseball antitrust issues unaffected by the Curt Flood Act keep the exemption controversy alive within the judiciary. See McCoy v. Major League Baseball, 911 F. Supp. 454, 457 (W.D. Wash 1995) (rejecting 
exemption, its practices would most likely be judged under the rule of reason standard. ${ }^{189}$ Hence, baseball's practices would not automatically be in violation of the antitrust laws if the exemption ceased to exist. $^{190}$

Debate also surrounds the potential adverse effects on the minor leagues should the exemption be completely abolished. The weight of expert opinion on the matter suggests that the minor leagues would survive if the exemption ceased to exist. ${ }^{191}$ In fact, some commentators have argued that the abolition of the exemption might leave the minor leagues better off both economically and in terms of quality. ${ }^{192}$

The State Oil Court was also concerned with the possible harm to manufacturers and consumers that might result if it upheld $\mathrm{Al}$ brecht's per se rule. ${ }^{193}$ While Toolson and Flood purportedly supported baseball's antitrust exemption based on the interests of the entire baseball industry, the Court actually seemed most concerned about the effect on the parties who would be sued should the ban be lifted: the owners and the League.$^{194}$ However, the Court should have

decisions that limit baseball's antitrust exemption to something less than the entire "business of baseball").

189. See Ross, Reconsidering, supra note 25, at 178 (citing NCAA v. Board of Regents of the Univ. of Okla., 468 U.S. 85 (1984), as grounds for supposing baseball would be subject to rule of reason analysis); Robbins, supra note 4, at 968 ("Because of the special nature of the business of professional sports leagues, a reviewing court would almost certainly apply the rule of reason analysis to a . . claim against [Major League Baseball].").

190. See Ross, Reconsidering, supra note 25, at 180 ("[B]aseball owners would be subject to a sophisticated and flexible rule of reason analysis that would permit them to agree on matters reasonably necessary to accommodate the sport's needs and the owners' legitimate interests.").

191. See Edmund P. Edmonds, Over Forty Years in the On-Deck Circle: Congress and the Baseball Antitrust Exemption, 19 T. MARSHALL L. REV. 627, 659 (1994) ("Although the loss of the exemption might create a significant restructuring in the financial relationship with Major League Baseball, the need for a system to generate major league talent [ensures the continuation of the minor league system]."); Smith, supra note 67, at 139 (stating that the impact on the minor leagues would be minimal); Zimbalist, supra note 163, at 303-06 (arguing that the claim that lifting the exemption will end minor league baseball is not credible); Charles Matthew Burns, Note, The Scope of Major League Baseball's Antitrust Exemption, 24 STETSON L. REV. 495, 496 n.8 (citing congressional testimony on the matter). But see Kohm, supra note 85, at 1254 ("[T] $]$ he effect of a repeal on the minor leagues would be difficult to predict.").

192. See Zimbalist, supra note 163, at 306 (suggesting that lifting the exemption "should be salutary for the minor leagues and their host cities," even considering the variety of restructuring possibilities in a postexemption era); Holding, supra note 163, at 5 (stating that the surviving minor league teams "would be better teams paying players a living wage and making majorleague owners compete for top talent with top dollar").

193. See State Oil Co. v. Khan, 522 U.S. 3, 18 (1997) ("Indeed, both courts and antitrust scholars have noted that Albrecht's rule may actually harm consumers and manufacturers.").

194. Both the Toolson and Flood Courts heavily stressed reliance concerns as reasons to abstain from abolishing the exemption. The League and owners are the parties that rely on the 
considered more seriously the entire baseball community, which includes the players (the labor) and the fans (the consumers). ${ }^{195}$ The injury to the laborers and consumers of baseball caused by the exemption is even more apparent today than it was in the time of Toolson or Flood. Owners' demands that players agree to excessive restrictions on competition have increased labor strife. ${ }^{196}$ The social cost of the strife has been evidenced in the frequent player strikes. ${ }^{197}$ In addition, fans and taxpayers are hurt financially by allowing owners to block the expansion or relocation of franchises. ${ }^{198}$ Through their monopoly power, owners have cost taxpayers millions in stadium subsidies, have kept franchises out of certain cities, and have made fans pay to view formerly free games on television. ${ }^{199}$ Depending on the specific plan, blanket restraint proposals such as salary caps ${ }^{200}$ or luxury taxes ${ }^{201}$ can "affirmatively harm competitive balance"202 and

exemption and have the most to lose if the exemption disappears. See supra notes $179-81$ and accompanying text.

195. See Stephen F. Ross, Monopoly Sports Leagues, 73 MinN. L. REV. 643, 644 (1989) [hereinafter Ross, Monopoly] ("The economic policy of the United States, as expressed in our antitrust laws, provides that firms should compete in an open and free marketplace to supply consumers with the best possible product at the lowest possible price and to allocate society's resources efficiently."). The owners assume an unusual position regarding the exemption. Owners benefit if they cannot be sued by players but they suffer if they cannot sue the league regarding marketing, relocation, and other issues specific to the individual franchise. Now, presumably, the owners will suffer more than before since the Curt Flood Act supposedly gives major league players antitrust remedies against the owners. See Curt Flood Act of 1998, Pub. L. No. 105-297, § 3, 112 Stat. 2824, 2824 (to be codified at 15 U.S.C. $§ 27 a$ ).

196. See Ross, Reconsidering, supra note 25, at 170.

197. See id. at 169 (noting that the 1994 strike marked the eighth consecutive time baseball had been interrupted following the expiration of a labor-management agreement); Smith, supra note 67, at 129-30 (stating that the 1994 players strike involved financial losses to cities, players, and owners in excess of one billion dollars). Ross also notes that "both players and consumers would have been better off if the players had the option of using the judicial system, rather than a work stoppage, to attack the salary cap." Ross, Reconsidering, supra note 25 , at 197 . But cf. Robbins, supra note 4, at 966 (arguing that repealing the antitrust exemption would do little except give players some procedural advantages). However, since the procedural advantages translate into recourse through the judicial system, the advantages may be significant. If procedural advantages turn out to be insignificant, see, e.g., Holding, supra note 163, at 5 (noting that despite antitrust recourse, labor strife has recently manifested itself in the 1998 NBA player lockout), the Curt Flood Act will be of little value.

198. See Ross, Reconsidering, supra note 25, at 170.

199. See id. at 196.

200. In short, salary caps constitute "a complex mechanism that limits the total amount each team can spend on players' salaries." Stephen F. Ross, The Misunderstood Alliance Between Sports Fans, Players, and the Antitrust Laws, 1997 U. ILL. L. REV., 519, 521 [hereinafter Ross, Misunderstood].

201. Luxury taxes are, in essence, punitive taxes on teams "with above average payrolls." Id. 
thus may be found illegal under the rule of reason analysis. Currently, however, such restraints might be shielded from judicial scrutiny by baseball's exemption. ${ }^{203}$ If the Court is truly concerned about the adverse effect on the laborers and consumers ${ }^{204}$ caused by upholding a rule that has had its theoretical underpinnings called into serious question, then the Court should overrule baseball's antitrust exemption just as it overruled the theoretical underpinnings of the per se rule in Albrecht.

\section{Principled Legal Reasoning}

The individual issues that the Supreme Court considers in its stare decisis review are part of a larger concern about the logic and legitimacy of the Court as an institution. The Supreme Court's power lies "in its legitimacy, a product of substance and perception that shows itself in the people's acceptance of the Judiciary as fit to determine what the Nation's law means and to declare what it demands." ${ }^{205}$ Therefore, "a decision without principled justification would be no judicial act at all." ${ }^{206}$ Accordingly, the Court must act in a way that allows people to accept the rationale underlying its decisions. ${ }^{207}$ The Court has explicitly acknowledged the importance of

202. Id. at 523. Whether the Curt Flood Act would cover such issues is unclear. See Holding, supra note 163, at 5 ("All [the Act] does is give players the option of disbanding their union and suing the owners for anti-competitive practices if league-contract negotiations don't go as the players want.").

203. See Ross, Misunderstood, supra note 200, at 522.

204. State Oil makes clear that the Court is concerned about consumers. See State Oil Co. v. Khan, 522 U.S. 3, 15 (1997) (concluding that Albrecht's per se invalidation of vertical maximum price fixing was unjustified because "condemnation of practices resulting in lower prices to consumers is "especially costly"' (citation omitted)). However, given the Flood decision, the Court appears to be less concerned about the labor involved in the baseball industry. See Flood v. Kuhn, 407 U.S. 258, 292 (1972) (Marshall, J., dissenting) ("We must not forget, however, that there are only some 600 major league baseball players. Whatever muscle they might have been able to muster by combining forces with other athletes has been greatly impaired by the manner in which this Court has isolated them.").

205. Planned Parenthood v. Casey, 505 U.S. 833, 865 (1992); see also Flood, 407 U.S. at 293 n.4 (Marshall, J., dissenting) (“" [H]owever admirable [a jurist's] resolute adherence to the law as it was, a decision contrary to the public sense of justice as it is, operates . . . to diminish respect for the courts and for law itself.'”) (quoting Peter L. Szanton, Stare Decisis; A Dissenting View, 10 Hastings L.J. 394, 397 (1959))

206. Casey, 505 U.S. at 865.

207. See id.; see generally Deborah Hellman, The Importance of Appearing Principled, 37 ARIZ. L. REV. 1107 (1995) (arguing that the Court must appear principled and give attention to how the public receives the reasons given for its decisions). However, the Court can lose legitimacy if it overrules too frequently or if it overrules simply because it is under fire politically 
principled legal reasoning and favors basing its decisions on reasoned analysis instead of formalistic line-drawing. ${ }^{20}$

When the views underlying precedent have changed so much that the precedent is called into question, the Court may rule that it is no longer bound by that precedent. ${ }^{209}$ In relating the legitimacy concern back to baseball's exemption, note that other professional sports do not enjoy the same antitrust exemption that baseball does. For the judicial system to subject affiliates of all other professional sports to antitrust penalties, while dismissing baseball antitrust complaints under the antitrust exemption, is illogical and unfair. ${ }^{210}$ In addition, the exemption appears to be more and more of an unnecessary anomaly given that other professional sports function without an antitrust exemption. For example, baseball lags behind basketball financially ${ }^{211}$ and has faced increasing pressure to adopt some National Football League practices such as revenue sharing. ${ }^{212}$ Adhering to a precedent that logic, practicality, and fairness have all abandoned would be a disservice to the legitimacy of the judicial system. As the State Oil Court pointed out, little can be salvaged of a decision that was criticized at its inception and which has subsequently been eroded both theoretically and practically. ${ }^{213}$

or socially. See Casey, 505 U.S. at 866-67.

208. See Continental T.V., Inc. v. GTE Sylvania Inc., 433 U.S. 36, 58-59 (1977) ("[D]eparture from the rule-of-reason standard must be based upon demonstrable economic effect rather than ... upon formalistic line drawing.").

209. See State Oil, 522 U.S. at 20-21 ("In the area of antitrust law, ... [there is an] interest ... in recognizing and adapting to changing circumstances and the lessons of accumulated experience."); see also Casey, 505 U.S. at 868 ("The promise of constancy, once given, binds its maker for as long as the power to stand by the decision survives and the understanding of the issue has not changed so fundamentally as to render the commitment obsolete.").

210. See Smith, supra note 67, at 124-25 ("[T] he [Major League Baseball Player's Association] is significantly weaker than other professional sports' players associations, because of its inability to challenge baseball's labor practices under federal antitrust laws.... [C]ollective bargaining remains the ... only means of redressing player grievances.”).

211. See Kurt Badenhausen et al., More Than a Game, FIN. WorLd, June 17, 1997, at 40, 42 (stating that basketball is the most profitable sport).

212. See Kevin E. Martens, Fair or Foul? The Survival of Small-Market Teams in Major League Baseball, 4 MARQ. SPORTS L.J. 323, 366-69 (1994) (discussing the labor and antitrust issues associated with revenue sharing); Baseball's Dilemma: How Can Small Market Teams Survive?, S.D. UNION-TRIBUNE, Jan. 13, 1999, at B8 (stating that baseball must adopt revenue sharing and salary caps similar to other professional sports in order to survive); Cheap Baseball, KANSAS CITY STAR, Dec. 18, 1998, at B6 (comparing baseball to football and stating that more revenue sharing is "the best way to make [baseball] more competitive"); Michael K. Ozanian, Valuation Scoreboard, FIN. WORLD, June 17, 1997, at 46, 46 (stating that baseball, like football, already revenue shares to some extent).

213. See State Oil, 522 U.S. at 21. 


\section{CONCLUSION}

The weakening of the positive inaction doctrine and the State Oil Court's affirmation that the Supreme Court has the power to overrule its prior antitrust decisions have seriously undermined the roadblock to judicial abolition of baseball's antitrust exemption that Toolson and Flood seemed to create. Furthermore, the confusion in the courts regarding the exemption's application has limited its general usefulness, and the reliance issues that serve as a bar to reversing precedent are not as great as the Toolson and Flood Courts may have feared. In fact, maintaining the exemption seems to foster more economic harm than good. Given the theoretical and practical undermining of the exemption's premises, the Supreme Court should dispose of the exemption through principled legal reasoning based on the legitimate factors that overcome stare decisis considerations. 